\title{
Türkiye'de Mali Müşavirlerin Mükellef Haklarına ve Gelir İdaresine Bakışını Etkileyen Faktörlerin Belirlenmesi'
}

\author{
Güneş ÇETIN GERGER, School of Applied Sciences, Celal Bayar University, Turkey; e-mail: \\ gunes.cetin@bayar.edu.tr
}

Feride BAKAR, Department of Public Finance, Faculty of Economics and Administrative Sciences, Uludag University, Turkey; e-mail: feridebakar@uludag.edu.tr

Adnan GERÇEK, Department of Public Finance, Faculty of Economics and Administrative Sciences, Uludag University, Turkey; e-mail: agercek@uludag.edu.tr

\section{Determining the Factors That Affect Certified Public Accountants' Perspective on Taxpayers' Rights and Tax Administration: A Research in Turkey $^{2}$}

\begin{abstract}
The perspective of taxpayers on the administration is an important indicator for ensuring tax compliance. Developed countries have conducted surveys of taxpayers to create a better taxation system and to determine taxpayers' perspective. However studies in Turkey in this field, remain only at theoretical level. To fill this gap, in this study, we examined the factors that determine perspective of certified public accountants' which conduct taxpayer's taxation works and have knowledge about taxation more, to analyze relationships between taxpayer's rights and resistance by means of structural equation modeling approach. The Model which was developed and called Resistance to Revenue Administration Model (RRAM) showed that taxpayers' right affects trust on tax administration and outcomes favorability affects resistance on tax administration directly.
\end{abstract}

Keywords : : Taxpayers' Rights, Tax Compliance, Tax Resistance, Tax Revenue, Structural Equation Modeling.

1 Bu makale TÜBİTAK tarafindan desteklenen 112K505 no'lu "Çeşitli Ülke Uygulamalarindan Hareketle Türkiye'de Mükellef Haklarının Geliştirilmesi" projesinin sonuçlarına dayalı olarak hazırlanan ve Sosyoekonomi Derneği ile Hacettepe Üniversitesi Piyasa Ekonomisini ve Girişsimciliği Gelişstirme Merkezi tarafindan Almanya'nın Münih şehrinde, 29-30 Ekim 2015 tarihlerinde düzenlenen "Birinci Uluslararast Sosyoekonomi Derneği Yıllık Buluşması" nda sunulan çalışmanın gözden geçirilmiş ve genişletilmiş halidir.

This article is based upon the results of a research project which is supported by TUBITAK and titled as "Çeșitli Ülke Uygulamalarından Hareketle Türkiye'de Mükellef Haklarinin Geliştirilmesi" and is the revised version of the paper presented in "First International Annual Meeting of Sosyoekonomi Society" which was held by Sosyoekonomi Society and CMEE - Center for Market Economics and Entrepreneurship of Hacettepe University, in Munich/Germany, on October 29-30, 2015. 
JEL Classification Codes : $\quad$ H21, H26, K34.

\section{$\ddot{\mathbf{O} z}$}

Vergi uyumunun sağlanmasında mükelleflerin idareye karşı algısı önemli bir konudur. Gelişmiş ülkeler daha iyi bir vergi sistemi tesis edilmesine katkıda bulunmak ve mükelleflerin bakış açılarını tespit etmek için çeşitli ampirik araştırmalar yapmaktadırlar. Fakat ülkemizdeki çalışmaların genelde teorik düzeyde kaldığı görülmüştür. Söz konusu boşluğu doldurmak için, bu çalışmada vergilendirme süreçlerinde mükelleflerden daha fazla bilgi sahibi olan ve onların şekli yükümlülüklerini yerine getiren mali müşavirlerin mükellef hakları algısı ve gelir idaresine bakışını belirleyen faktörler tespit edilerek, yapısal eşitlik modeli yardımıyla analiz edilmiştir. Geliştirilen ve Gelir İdaresine Direnç Modeli (GIDiM) olarak adlandırılan model, mükellef haklarının gelir idaresine güveni ve idare tarafından alınan kararların uygunluğunun ise gelir idaresine direnci doğrudan en fazla etkileyen faktörler olduğunu göstermiştir.

\section{Anahtar Sözcükler}

Mükellef Hakları, Vergi Uyumu, Vergi Direnci, Gelir İdaresi, Yapısal Eşitlik Modeli.

\section{Giriş}

Ülkelerde gelir idareleri mükellef odaklı bir yapıda yeniden organize edilirken, mükelleflerin görüşlerinin alındığ ve bunlara göre düzenlemelerin yapıldığ 1 bir süreç ortaya çıkmıştır. Vergi uyumunun sağlanmasında mükelleflerin gelir idaresine karşı algısı önem arz etmektedir. Bu yüzden, hem ülkelerdeki gelir idareleri hem de araştırmacılar mükelleflerin bakış açılarını tespit etmek üzere alan araştırmalarıyla çeşitli ölçümler yapmaktadirlar.

Mükellef odaklı yaklaşımla beraber mükellef hakları da önem kazanmış ve bu hakları inceleyen çalışmalar yapılmaya başlanmıştır. Özellikle ülkelerde mükellef haklarının durumunun ve gelişiminin nasıl algılandığının tespitine yönelik düzenli ampirik ölçümler yapılmıştır. Ülkemizde ise mükellef haklarına ve gelir idaresine bakışı etkileyen faktörleri tespit etmeye yönelik kapsamlı ampirik çalışmaların yokluğu dikkat çekicidir.

$\mathrm{Bu}$ çalışmanın amacı, vergilendirme süreçlerinde mükelleflerden daha fazla bilgi sahibi olan ve aynı zamanda mükelleflerin yükümlülüklerini yerine getirirken onlarla birebir ilişki içinde olan mali müşavirlerin mükellef hakları algısı ve gelir idaresine bakışını belirleyen faktörlerin tespitiyle bunların yapısal eşitlik modeli yardımıyla analiz edilmesidir. $\mathrm{Bu}$ amaçla çalışmada ilk olarak verginin pasif öznesi olarak mükellefin ve temsilcisi olan mali müşavirin durumuna, sonrasında ise mali müşavirlerin gelir idaresine bakışını belirleyen faktörlerin tespitine, daha sonra anket sonuçlarını oluşturan verilerin analizine ve son olarak da Türkiye için önerilere yer verilmiştir.

\section{Verginin Pasif Öznesi Olan Mükellefin ve Mali Müşavirin Durumu}

Devletin en önemli gelir kaynağı olan verginin, eksiksiz ve zamanında toplanması, vergi borçlusu olan mükellefin ve alacaklı olan devletin ilişkilerinin doğru 
kurulması ve vergi uyumu düzeyinin artması ile mümkün olur. Bu ilişkide iki taraf vardır: bunlardan biri olan verginin aktif öznesi (aktif süje), egemenlikten kaynaklanan vergileme yetkisini kullanan devlet ve/veya yetki devrettiği kamu tüzel kişileridir, diğeri ise konumları vergi kanunlarınca tanımlanan ve verginin pasif öznesi (pasif süje) konumunda olan vergi mükellefidir (Muter vd., 1993: 5). Karşılıklı olan bu ilişkide devletin tek taraflı olarak koyduğu vergiler, verginin pasif öznesi olan mükellefler tarafından benimsenmezse, sürecin sağlıklı ve etkin işlemesi mümkün olmaz (Yüce, 1999). Bu sebeple vergi sisteminin oluşturulmasında devlet, tek taraflı bir yaklaşımla düzenlemeler yapmamalı, aksine mükelleflerin sisteme ilişkin değerlendirmelerini de göz önüne almalıdır (Muter vd., 1993: 5). Özellikle pasif vergi öznesi olan mükellefin aktif vergi öznesi olan devlet karşısında sadece yükümlülüklerinin değil, haklarının da olduğunun açıklanması ve hukuki metinlerde düzenlenmesi gerekir (Erol, 2011).

Verginin pasif öznesi olan yükümlülerin tepkilerinin dikkate alınması, oluşturulacak vergi politikalarının etkinliği açısından önem taşır (Çiçek, 2005: 44). Mükellefler ile işbirliği sonucu, katılımcı bir politikanın izlenmesi diğer bir deyişle mükelleflerin politik karar alma sürecine yaygın ve etkin bir şekilde katılması durumunda, onlar devletin kendilerine adil davrandığını hisseder, ödedikleri vergiler ve kamu yatırımları arasında doğru orantı kurarlar. Aktif katılım, yasalar ve politikacılar üzerinde mükelleflerin kontrol kabiliyetini yükseltir ve onların gönüllü uyumlarını pozitif etkiler (Strümpel, 1969'dan aktaran; Tuay \& Güvenç, 2007: 24). Bu yüzden mükelleflerin, kendi hakları ile ilgili bilgi sahibi olması ve vergileme sürecine aktif katılımları önemlidir.

Günümüzde gelir idarelerine hâkim olan "mükellef odaklı" hizmet anlayışı, mükellefe rağmen değil mükellefle birlikte vergilemeyi kabul ederek; mükelleflerin görüşlerinin alındığ 1 , buna göre düzenlemelerin yapıldığ1, belirli periyodlarla görüş değişikliklerinin izlendiği ve bunun sonucunda sistem üzerinde gerekli revizyonların gerçekleştiği bir süreci oluşturmuştur (Gerçek, 2006: 122; Bakar, 2011: 40). Aslında mükellef - idare ilişkisi dolaylı bir ilişkidir. Mükellefler vergileme ile ilgili şekli ödevlerini genellikle onların mali temsilcileri olan muhasebeci veya mali müşavirleri aracılığıyla yerine getirirler. Özellikle e-vergilendirme sistemlerinin kullanımının zorunlu olduğu ve bu sebeple e-beyannamelerin meslek mensupları tarafından gönderildiği Türkiye gibi ülkelerde onların temsilci olma konumlarının önemi daha da ön plandadır (Gerçek vd., 2015a: 106). Meslek mensupları bu konumları gereği mükelleflerin idare ve vergilendirme hakkındaki görüşleri üzerinde etkili olurlar. Bu açıdan değerlendirildiğinde mükellef hakları algısı ile gelir idaresine güven duyma ve/veya direnç gösterme tutumu incelenirken, mükelleflerin görüşlerinin alınması kadar meslek mensuplarınınkine de başvurulması gerekir. 
Çetin Gerger, G. \& F. Bakar \& A. Gerçek (2016), “Türkiye'de Mali Müşavirlerin Mükellef Haklarına

ve Gelir İdaresine Bakışını Etkileyen Faktörlerin Belirlenmesi”, Sosyoekonomi, Vol. 24(29), 45-71.

\section{Türkiye'de Mali Müşavirlerin Mükellef Haklarına ve Gelir İdaresine Bakışı}

\subsection{Türkiye'de Mükellef Haklarının Durumu}

90’lı yıllardan sonra ortaya çıkan gelir idarelerinin "mükellef odaklı yaklaşımla" yeniden yapılandırılması ile vergileme sürecinin etkin, adil ve şeffaf hale getirilmesi çalışmalarına paralel olarak birçok ülkede mükellef haklarının belirlenmesi, açıklanması, korunması ve denetlenmesi gibi hususlar gündeme gelmiş̧ir. Bu gelişmelerde ortaya çıkan gelir idarelerinin mükelleflere yönelik bakış açısının değişim, vergi sistemlerindeki karmaşıklığın giderilmesi, mükelleflerin seçmen olarak önem kazanması, uluslararası alanda meydana gelen gelişmeler ve teknolojik yenilikler mükellef haklarının önemini artırmıştır (Gerçek vd., 2015b: 25).

Mükellef hakları aslında, devletin geniş vergilendirme yetkisini mükellef lehine sınırlandırma düşüncesinin bir sonucudur (Brzezinski, 2009: 17). Mükellef hakları, genel olarak gelir idaresinin yaptığı vergilendirme ile ilgili tüm eylem ve işlemlere mükellef perspektifinden bakabilmesi sürecidir (Dönmez, 2004: 57). Mükellef haklarının ilgili ülke mevzuatında yer alması mükelleflerin devlete olan güvenlerini olumlu yönde etkilemekte ve onların gönüllü uyumlarını sağlamaktadır (Çetin Gerger, 2011: 13). Mükellef haklarının yasal düzenlemelerle oluşturulması, düzenlenmesi, anlaşılabilir ve erişilebilir hale getirilmesi mükelleflerin ve onların mali temsilcilerinin devlete olan güven duygularının artmasında, adalet algılarının güçlenmesinde, vergiye karşı dirençlerinin azalmasında oldukça etkilidir (Bkz. Gerçek vd., 2015b; Çetin Gerger, 2011).

Mükellef hakları anayasa, uluslararası sözleşme, yasa, idari düzenleyici işlemlerde yer alan, asli ve tali bir dizi haklar bloğudur (Yaltı, 2006: 3). Mükellef hakları; hukuk sisteminde var olan temel insan haklarından kaynaklanan; anayasa, uluslararası anlaşma, kanun veya idari düzenlemelerle korunan, vergileme işlemi sırasında vergi mükelleflerinin ileri sürebilecekleri haklar olarak tanımlanabilir (Gerçek vd., 2015a: 19).

Mükellef hakları ülkelerdeki vergi sistemlerine göre farklılık gösterebilmektedir. Mükelleflerin karmaşık vergi kanunlarının içerisinde haklarını daha iyi anlayabilmeleri için mükellef hakları sistematik bir şekilde sınıflandırılmıştır. Birinci grup haklar vergi kanunlarının uygunluğu ile ilgili olan ve temel insan hakları çerçevesinde tüm mükelleflerin sahip olduğu hakları içerir ve "mükellefin genel hakları" olarak ifade edilir. Diğer grup ise vergi kanunlarının uygulanması ile ilgili ortaya çıkan özel durum ve işlemler sırasında mükelleflere tanınan ve ülke mevzuatına göre farklılık gösterebilen hakları içerir. Bu haklar da "mükellefin özel hakları" biçimde adlandırılır (Bentley, 1998: 4).

Dünya genelinde birçok ülke gelir idaresi; yasal veya idari olarak mükellef haklarını sistematik şekilde düzenleyen faaliyetleri gerçekleştirmektedir. Kanunlarda mükellef haklarıyla ilgili ayrı bir bölüm halinde düzenleme yapılması ve bu hakların mükellef hakları bildirgelerinde açıklanması; vergilendirme işleminin tarafları arasındaki 
ilişkilerin geliştirilmesine yardımcı olmakla birlikte vergi sisteminin tüm açılardan etkin bir şekilde çalışmasına katkı sağlamaktadır (TCIT, 2008: 8). İngiltere (1986), ABD (1988), Avustralya (1997) ve İtalya (2000) gibi bazı ülkeler mükellef haklarını açıklama yoluna gitmiş iken, son on yıl içinde İspanya (2003), Fransa (2005) ve Kanada (2007) gibi birçok ülke temel mükellef hak ve yükümlülüklerini "Mükellef Bildirgesi" veya "Servis Standartları" şeklinde oluşturmuş ve açıklamıştır. Hatta mükellef haklarını daha önce açıklayan Avustralya (en son 2010), İngiltere (en son 2013), ABD (en son 2014) mükellef haklarını daha iyi anlatabilmek için tekrar düzenlemeler yapmışlardır (Gerçek vd., 2015b: 233). Aşağıdaki Tablo 1'de OECD üyesi ülkelerde mükellef haklarıyla ilgili düzenlemelere yer verilmiştir.

Tablo: 1

OECD Ülkelerinde Mükellef Haklarıyla İlgili Düzenlemeler

\begin{tabular}{|c|c|c|c|c|c|}
\hline ÜLKELER & $\begin{array}{c}\text { Kanun Olarak } \\
\text { ya da Diğer } \\
\text { Yasal Statüde } \\
\text { Düzenleme }\end{array}$ & $\begin{array}{c}\text { İdari Bir Belge } \\
\text { Niteliğinde } \\
\text { Düzenleme }\end{array}$ & ÜLKELER & $\begin{array}{c}\text { Kanun Olarak } \\
\text { ya da Diğer } \\
\text { Yasal Statüde } \\
\text { Düzenleme }\end{array}$ & $\begin{array}{c}\text { İdari Bir Belge } \\
\text { Niteliğinde } \\
\text { Düzenleme }\end{array}$ \\
\hline $\mathrm{ABD}$ & Var & Var & İtalya & Var & Var \\
\hline Almanya & Var & Yok & İzlanda & Var & Yok \\
\hline Avustralya & Var & Var & Japonya & Var & Yok \\
\hline Avusturya & Var & Var & Kanada & Var & Var \\
\hline Belçika & Var & Var & Güney Kore & Var & Var \\
\hline Çek Cumhuriyeti & Var & Yok & Lüksemburg & Var & Var \\
\hline Danimarka & Var & Var & Macaristan & Var & Var \\
\hline Estonya & Var & Yok & Meksika & Var & Var \\
\hline Finlandiya & Var & Var & Norveç & Var & Var \\
\hline Fransa & Var & Var & Polonya & Var & Yok \\
\hline Hollanda & Var & Var & Portekiz & Var & Var \\
\hline İngiltere & Var & Var & Slovakya & Var & Yok \\
\hline İrlanda & Yok & Var & Slovenya & Var & Var \\
\hline İspanya & Var & Var & Şili & Var & Var \\
\hline İsrail & Var & Var & Türkiye & Yok & Var \\
\hline İsveç & Var & Var & Yeni Zelanda & Yok & Var \\
\hline İsviçre & Var & Yok & Yunanistan & Var & Var \\
\hline
\end{tabular}

Kaynak: OECD, Tax Administration 2013: Comparative Information on OECD and Other Advanced and Emerging Economies, OECD Publishing, 2013, <http://www.oecd-ilibrary.org/taxation/ tax-administration2013_9789264200814-en>, 26.09.2015.

Tablo 1'den de görüldüğü gibi, OECD'ye üye 34 ülkeden 31 'inde mükellef haklar1 konusunda vergi kanunu veya benzer statüde kısmen veya tamamen düzenleme yapılmıştır. 26 tanesinde ise mükellef hakları "Mükellef Bildirgesi" veya "Servis Standartları" olarak set halinde idari belgelerle düzenlenmiştir. Türkiye'de 2005 yılında Gelir İdaresi Başkanlığı kurularak vergi idaresinin yeniden yapılandırılması gerçekleştirilmiştir, bu süreçten sonra idare 2006 yılında Mükellef Hakları Bildirgesini internet sitesinde yayınlamıştır (Çetin Gerger \& Yücedoğru, 2012: 142). Fakat bu bildirgenin en iyi uygulamalara sahip olan ülkelerdeki bildirgelere göre mükellef haklarını açıklamada yetersiz kaldığı ve daha ziyade gelir idaresinin mükelleflere yönelik hizmet 
taahhütnamesi niteliği taşıdığı anlaşılmaktadır. OECD üyeleri içinde, hukuki mevzuatında mükellef haklarıyla ilgili sistematik bir düzenlemeye yer vermeyen üç ülkeden biri ise Türkiye'dir. Türk Vergi Hukuku'nda mükellef haklarının önemli bir kısmı aslında mevcuttur (Gerçek, 2006: 138). Fakat burada özellikle sistematik bir düzenlemenin önemi ortaya çıkmaktadır. Ülkemizde mükellef hakları konusunda bir diğer eksiklik ise mükellef hakları algısını ve gelir idaresine bakışı ölçmeye yönelik saha çalışmalarının bulunmamasıdır.

\subsection{Mali Müşavirlerin Mükellef Haklarına ve Gelir İdaresine Bakışını Belirleyen Faktörler}

Dünyada mükelleflerin, vergi sistemi ve vergilendirme karşısındaki davranışları ve bunların araştırılması, özellikle gelişmiş ülkelerdeki gelir idarelerinin ilgisini çekmiştir (Marti vd., 2010: 112). Yapılan bu araştırmalar vergi uyumunu artırılmasında değerlendirilecek bir veri seti olarak oluşturarak, gerekli önlemlerin alınmasında ve daha etkin verimli ve başarılı gelir idarelerinin oluşmasında kullanılmaktadır. Yapılan çalışmalar, vergi uyumunun gerçekleştirilmesi konusundaki önlemler ve vergi direncinin azaltılması hedeflerini kapsayan bir alanda toplanmaktadır. Ülkemizde de mükelleflerin vergileme karşısındaki tutum ve davranışlarını etkileyen faktörleri belirlemek için birçok çalışma yapılmıştır (Bkz. Tuay \& Güvenç, 2007; Baloğlu vd., 2010; Altuğ vd., 2010).

OECD ülkelerinin çoğu ve gelir idarelerini yeniden yapılandıran bazı diğer ülkeler, mükellef haklarının gelişmesini ve yaygınlaşmasını sağlamak için bir taraftan açık ve anlaşılır yasal ve idari düzenlemeler yaparken, diğer taraftan mükellef hakları algısı ve mükelleflerin gelir idaresine bakışını periyodik olarak ölçerek mükellef - vergi idaresi ilişkilerini geliştirmeye yönelik çeşitli tedbirler almaktadırlar. Bu konuda özellikle Avustralya'da yoğun çalışmaların yapıldı̆̆ı görülmektedir. James, Murphy ve Reinhart (2005b) özellikle mükelleflerin hakları ile ilgili algılarının ne yönde olduğunu ortaya koymuşlardır. ATO (2009) ile Murphy ve Murphy (2010) tarafından yapılan çalışmalar ise, mükellef hakları alanında periyodik olarak tekrarlanmakta ve mükelleflerin algısının zaman içinde ne yönde değiştiğini raporlama amacını taşımaktadır.

Mükelleflerin mali temsilcilerinin vergi uyumunun sağlanmasındaki rollerini değerlendirdiğimizde, onların gelir idaresi ile mükelleflerden daha yakın ve sıkı bir ilişki kurduğunu söyleyebiliriz. Mükellefler açısından mali müşavirler, öncelikle doğrudan ve hızlı bir bilgi kaynağıdır. Örneğin vergileme ile ilgili bilgilerin öğrenildiği kaynağın sorulduğu bir anket çalışmasına katılan mükelleflerin \%63.8'si “serbest muhasebeci mali müşavirlerden" yanıtını verirken, ankete katılanlardan hiç kimse vergileme konusunda bilgi kaynağı olarak vergi dairelerini göstermemiştir. Bu çarpıcı sonuçtan anlaşılacağı üzere meslek mensuplarının vergi ilişkisinde mükellefleri aydınlatıcı bir işlevi bulunmaktadır (Gerçek, Yüce, 1998: 64). Ayrıca vergi ödevlerini zamanında eksiksiz yerine getirmeleri konusunda yardımcı ve köprü konumda yer almaktadırlar. Bu yüzden, yalnızca mükellefler ile yapılacak bir araştırma eksik kalacaktır. 
Mükellef hakları ve gelir idaresine bakışı belirleyen faktörler ile idareye olan güven ve direnç arasındaki yapısal ilişkiler Murphy (2004), Murphy ve Byng (2002) ve James, Murphy ve Reinhart (2005b)'den yararlanılarak saygı, danışma ve bilgi verme, güvenilir muamele, adalet ve tarafsızlık, uygun çıktılar, teknoloji kullanımı, güven ve direnç olarak belirlenmiştir. Bu faktörlere Çetin Gerger (2011) ve Hung, Chang ve Yu (2006)'dan mükellef haklarına ve teknoloji kullanımı yaklaşım faktörleri adapte edilmiştir.

\subsubsection{Sayg1}

Gelir idaresinin gösterdiği saygılı ve özenli davranışların nedeni, mükelleflerin bu saygılı muamele sonucu daha az olasılıkla vergi kaçıracağı yönündeki düşüncedir. Saygılı ve özenli davranışlar mükelleflerin "doğru şeyi yapma" tutumları üzerinde etkili olmaktadır. Mükellef haklarını açıklayan bildirgelerde de mükelleflerin dürüstlüğü karinesi yaklaşımı içinde hizmet sunulacağı taahhüt edilir (Walsh, 2012: 6). Hizmetleri sunarken kendilerine tarafsız ve saygılı davranma konusunda çaba harcandığına inanan bireylerin idareye olan güven artışı, bunun tersine inanan kişilerin aksine yasalara uyma konusunda özen göstermelerine sebep olur (Tunçer, 2002: 117). Saygılı muamele görmek aynı zamanda mükelleflerin idareden bekleyebilecekleri temel hakları arasında yer almaktadır.

\subsubsection{Mükellef Haklarına Yaklaşım}

Mükellef haklarının varlığı mükellef ile gelir idaresi ilişkisini geliştirir. Araştırmalar da göstermektedir ki, bu ilişki iyi olursa gönüllü uyum gelişecek ve devletin gelir kaybetme riski düşecektir (Bentley, 2002). Gönüllü uyumu artırmak için günümüzde gelir idareleri işlemleri mümkün olduğunca basit, kolay yapmaya ve hizmetleri kişiselleştirmeye çalışmaktadırlar. $\mathrm{Bu}$ sebeple bildirgelerde gelir idaresi tarafından sistematik bir şekilde açıklanan mükellef hakları mükelleflere hak ve yükümlülükleri konusunda basit, anlaşılır ve ulaşılabilir bilgi vererek, onlarla işbirlikçi bir ilişki kurmayı amaçlar (OECD, 2003: 4). Bu işbirlikçi ilişki mükelleflerin idareye bakışı üzerinde etkili olacaktır. Çünkü mükelleflerin kendi haklarını açıklayan, koruyan ve bunların uygulanmasına yönelik işlemleri gerçekleştiren bir idare karşısındaki tutumları daha olumlu olacaktır.

\subsubsection{Danışma ve Bilgi Verme}

Mükelleflerin gelir idaresine güvenlerinin artması ve dirençlerinin azalması için onları teşvik edici bir ortam tesis edilmelidir. Bu ortamın sağlanabilmesi genel rehberlik, danışma ve kamu ilişkileri sonucu mükellef ile karşılıklı bir iletişim süreci oluşturarak yapılabilir (James, Murphy, Reinhart, 2005a: 15). Gelir idaresi mükelleflere vergilemedeki değişiklikler hakkında danışmanlık yapmalı ve yararlı bilgileri onlara vermelidir. Bu danışma sürecinin başarısı mükellefleri pozitif olarak etkilemektedir (Çetin Gerger vd., 2013: 4). 


\subsubsection{Güvenilir Muamele}

Mükelleflere güvenilir hizmet sunulması, onların bilgilerinin güvenli bir şekilde saklanması ve kişisel bilgilerine saygı gösterilmesi onların gelir idaresine güven duymaları açısından önemlidir. Güvenilir muamele, mükelleflerde vergileme işlemlerinin usulüne uygun olarak yürütüldüğüne ilişkin güçlü kanaat oluşturmaktadır (Murphy, 2004: 199). Dolayısıyla güvenilir muamele gören mükelleflerin gelir idaresine olan güvenleri arttığından, idareye karşı husumetleri ve dirençleri azalmakta, vergiye gönüllü uyumları sağlanmaktadır (OECD, 2004: 42).

\subsubsection{Adalet ve Tarafsızlık}

Üç tür adaletten bahsedilir (OECD, 2010): Dağıtıcı adalet (Devletin vergi gelirlerini akıllıca harcadığı algısı); Prosedürel adalet (Gelir idaresinin mükellefle ilişkili prosedürlerde adil olduğundan emin olma algısı); ve Cezalandırıcı adalet (Gelir İdaresinin kurallar ihlal edildiğinde cezaları uygularken adil olduğu alg1sı). Son ikisi Gelir İdaresi ile daha yakın ilişkilidir ve Gelir İdaresi tarafından etkilenebilir (Walsh, 2012: 455). Eğer vergi mükellefleri verginin adil bir şekilde toplandığına ve gelirin de akıllıca harcandığına inanmazlar ise vergi uyumsuzluğu artacaktır. (Murphy, 2004: 203). Bu yüzden vergi uyumunu artırmada adalet algısına dikkat edilerek düzenleme yapılması önemlidir. Mükelleflerin gelir idaresine olan güveni ve direnci etkileyen faktörler arasında idarenin profesyonel, tarafsız ve adil yaklaşımı yer almaktadır (GİB, 2007b: 43). Mükellefler vergi kanunlarının uygulanması sırasında diğerlerine göre adaletsiz bir tutumla karşılaştıklarında idareye bakışları olumsuz yönde etkilenecektir (Çelikkaya, 2002). Araştırmalar, gelir idaresi tarafından adil muamele gördüğünü düşünen kişilerin, idarenin kararlarını kabul etmek ve ona güven duymak konusunda daha fazla eğilimli olduğunu göstermiştir (Tyler, 1997). Bu yüzden, vergi uyumunu artırmada adalet ve tarafsızlık algısına dikkat edilerek düzenleme yapılması önemlidir (Murphy, 2004: 203).

\subsubsection{Uygun Çıktılar}

Mükelleflerin gelir idaresinin yapacağı işlemlerin usulüne uygun olduğu yönündeki inancı, onların idareye olan bakış açılarını etkiler (Murphy, 2004: 4). İşlemlerin yasalara uygun olmasının mükelleflerle ilişkilerde işlevsel olarak pozitif bir etkisi vardır. Gelir idareleri de mükellefle olan ilişkilerinin önemli bir parçasının yasalar aracılığıyla kurulduğunu kabul eder (Tyler, 1997). Ayrıca idarenin işlemleri sonucunda oluşan uygun çıktılar, gelir idaresine olan güveni geliştirerek, üçüncü kişilerin davranışları üzerinde de pozitif etki yaratacaktır (Çetin Gerger vd., 2013: 4). Bireyler idarenin tüm işlemlerinin usulüne uygun yapıldığına inanırlarsa idareye bakış açıları da bundan olumlu şekilde etkilenecektir. 


\subsubsection{Teknoloji Kullanımı}

Günümüzde e-devlet uygulamalarından en çok yararlanan kurumların başında gelen gelir idaresi, bu yolla mükelleflerin kendisine olan bakış açısında etkili olmaktadır (Demirbaş vd., 2012: 61). e-Vergilendirme bir yandan gelir idaresinin iş akış sistemleri ve elektronik kayıt yönetimini, diğer yandan da vergi beyannamelerinin güvenilirliğini değerlendirmek için otomatik risk analizi ve bilgi yönetimi işlemlerini desteklemelidir. Bu izlenen süreçlerden hepsi ya da bazıları mükellefin davranışını etkilemek için doğrudan ya da dolaylı olarak kullanılabilir (Walsh, 2012: 23). Vergilemede teknoloji kullanımı mükelleflerin gelir idaresine karşı direncini azaltır ve vergiye uyumunu artırır (Schaupp vd., 2010: 641).

\subsubsection{Güven}

Genel olarak güven; vergi otoritelerinin mükellefin dürüstlüğüne sayg1 göstermesi ve mükellefe saygı değer muamele ve mükellefin oyunun kurallarına uyması yönünde özendirici olmasıdır (Feld \& Frey, 2002: 92). Güven, mükellefleri gönüllü uyuma sevk ederken vergileme işlemlerine yardımcı olması sürecinde ortaya çıkar. Güveni kurmak için, vergi halktan şeffaf bir şekilde toplanmalı ve adalet algısı önemsenmelidir (Walsh, 2012: 456). Vergilemeye, gelir idaresine ve yarg1 sürecine karş1 güven içinde olmayan mükelleflerin vergiye uyum göstermesi zordur (Çelikkaya, 2002). Mükelleflerin gelir idaresine güven duyması, öncelikle işbirlikçi bir yaklaşım sergilemesini ve aynı zamanda direnç veya uyumsuzluk alanlarının azalmasını sağlar. Bu durum ise vergi uyumunda en iyi uygulama yöntemlerinin ortaya çıkmasına yardımcı olur (Murphy, 2004: 203).

\subsubsection{Direnç}

Mükelleflerin vergi ödemeye karşı direnç tutumu, vergi kaçakçılığı ve vergiden kaçınma davranışlarının en önemli nedenlerinden biridir (Gök, 2007: 146). Görülen bu direnç davranışı gelir idaresinin eylemlerine karşı da gözlenebilmektedir. Mükellefin direnç tutumu kendi öz-denetim sistemine aktif olarak direnç göstermesi olarak tanımlanır. Direnç gösteren bireyler gelir idaresine husumetle bakarlar. Bunun sebebi mükelleflerin idarenin kendilerine yardım etmek yerine onların yanlışlarını bir an önce yakalamayı tercih edeceği yönündeki düşünceleridir. Ayrıca gelir idaresine karşı direnç içinde olan bireyler, bunun sonucunda bir duruş sergilenmesi gerektiğine inanırlar (Murphy, 2005: 5). 
Çetin Gerger, G. \& F. Bakar \& A. Gerçek (2016), “Türkiye'de Mali Müşavirlerin Mükellef Haklarına

ve Gelir İdaresine Bakışını Etkileyen Faktörlerin Belirlenmesi”, Sosyoekonomi, Vol. 24(29), 45-71.

\section{Türkiye'de Mali Müşavirlerin Mükellef Haklarına ve Gelir İdaresine Bakışını Belirlemeye Yönelik Araştırma}

\subsection{Araştırmanın Amacı ve Önemi}

Dünyadaki vergi idarelerinde görülen mükellef odaklı gelişmelere paralel olarak, ülkemizde Gelir İdaresi Başkanlığı da son y1llarda mükelleflerin görüşlerini almak için "memnuniyet anketi" uygulamaya başlamıştır. $\mathrm{Bu}$ anket mükelleflerin vergi idaresi hizmetlerinden memnuniyetini ölçerek mükellef - gelir idaresi ilişkilerinin geliştirilmesi açısından önemli olmakla birlikte, mükelleflerin gelir idaresine bakışını belirleyen faktörleri tespit edecek şekilde gruplandırılmadı ğı için yeterli değildir. Ülkemizde akademik anlamda yapılan mükellef hakları konusundaki algıyı ve gelir idaresine bakışla ilgili faktörlerin gelir idaresine güven duyulması veya direnç gösterilmesi üzerindeki etkiyi belirleyen bir anket çalışmasına da rastlanılmamıştır. Bu sebeple mükellefler ile gelir idaresi arasında bir köprü konumunda olan ve onların vergileme işlemlerini yürüten serbest muhasebeci mali müşavirlerin gelir idaresine bakışını ve direncini belirleyen faktörlerin neler olduğu bilinmediğinden, mükellef haklarının geliştirilmesi için alınacak tedbirler ve izlenecek politikalarda tek taraflı bir yaklaşım izlenmek zorunda kalınmaktadır.

$\mathrm{Bu}$ çalışmanın amacı ilk defa Türkiye genelinde mükellef hakları algısı ve gelir idaresine bakışı bir anket yardımıyla analiz ederek, gelir idaresine güven duyma ve/veya direnç göstermeye yönelik faktörleri yapısal eşitlik modellemesi yaklaşımı ile analiz etmektir. Yapılan bu çalışma sayesinde Türkiye'de mükellef - gelir idaresi ilişkilerini belirleyen faktörleri tespit etmeye yönelik bir veri seti oluşturulacaktır. Böylece bu alanda ileride yapılacak araştırmalara ve en iyi uygulamalara sahip ülkelerde olduğu gibi ülkemizde de periyodik ölçümlere önemli bir altyapının oluşması sağlanacaktır. Anketin mükelleflerin vergileme işlemlerini yürüten ve mükellef hakları konusunda mükelleflerden daha fazla bilgi sahibi olan serbest muhasebeci mali müşavirlere yapılması sonucunda gerçekleştirilebilecek daha somut öneriler ortaya çıkarılabilecektir.

\subsection{Araştırma Modelinin Geliştirilmesi ve Test Edilecek Hipotezler}

Mali müşavirlerin gelir idaresine bakışını ve direncini belirleyen faktörleri tespit etmek için Murphy (2004) tarafından geliştirilen yapısal eşitlik modeli esas alınmıştır. Murphy (2004), Murphy ve Byng (2002) ve James, Murphy ve Reinhart (2005b) gelir idaresine bakışı doğrudan belirleyen altı tane faktör olduğunu tespit etmişlerdir. Bunlar: danışma, güvenilir muamele, saygı, tarafsızlık, adalet ve uygun çıktılardır. Bu çalışmada söz konusu modeli geliştirmek amacıyla mali müşavirlerin gelir idaresine güveni ve direncini etkileyen bir faktör olarak "Mükellef Haklarına Yaklaşım” Çetin Gerger (2011)'den ilk defa uyarlanmıştır. Ayrıca meslek mensuplarının gelir idaresine güveni ve direncini etkileyen bir diğer faktör olarak "Teknoloji Kullanımı" Hung, Chang ve Yu (2006) ve Schaupp, Carter ve McBride (2010)'dan alınarak ilk defa modele dahil edilmiştir. Analizde kullanılan yapısal eşitlik modelleme yaklaşımı, doğrudan ölçülemeyen örtük değişkenler arası ilişkilerin 
incelenmesinde diğer yöntemlere göre üstün olup, son yıllarda sosyal bilimler alanında yaygın olarak uygulanmaktadır (Bkz. Kline, 2011; Pugesek vd., 2003; Taşkın \& Akat, 2010).

$\mathrm{Bu}$ araştırmada, mali müşavirlerin gelir idaresine duydukları güven ve dirençlerini test etmek için kullanılacak model aşağıda gösterilmiştir (Bkz. Şekil 1):

Şekil: 1

\section{Önerilen Araştırma Modeli}

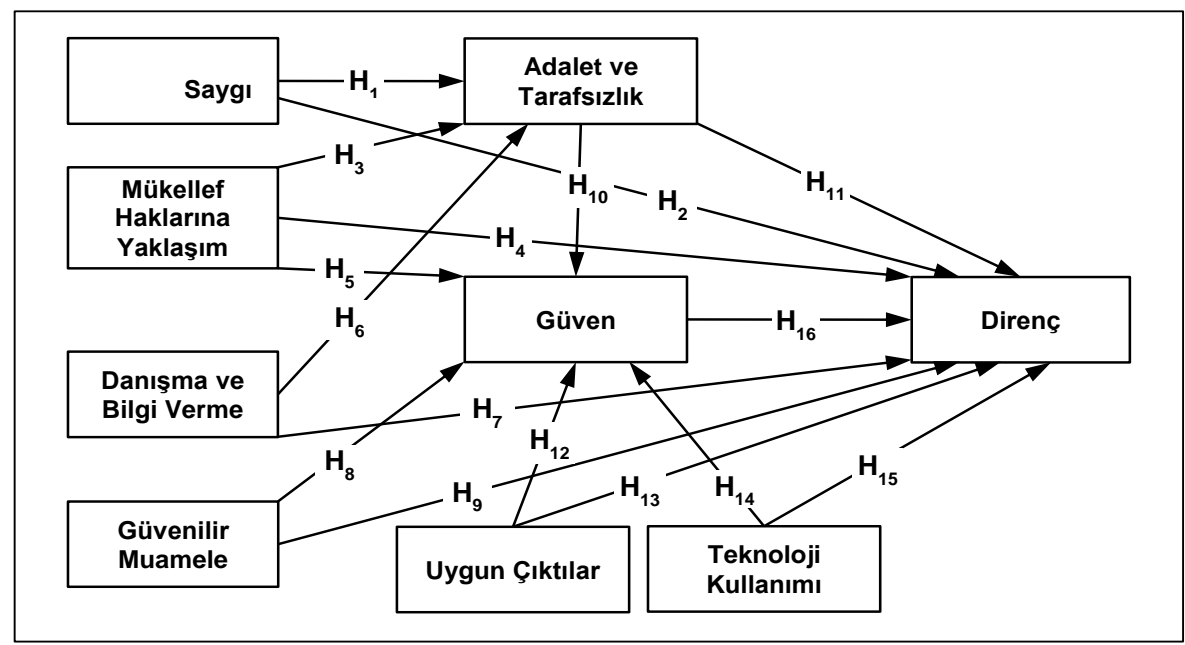

Modelde yer alan ve test edilecek olan araştırma hipotezleri aşağıdaki şekildedir:

H1: "Saygı" değişkeninin “Adalet” değişkeni üzerinde pozitif etkisi vardır.

H2: "Saygı" değişkeninin "Direnç" değişkeni üzerinde negatif etkisi vardır.

H3: "Mükellef Hakları" değişkeninin "Adalet" değişkeni üzerinde pozitif etkisi vardir.

H4: "Mükellef Hakları" değişkeninin "Direnç" değişkeni üzerinde negatif etkisi vardir.

H5: "Mükellef Hakları" değişkeninin "Güven” değişkeni üzerinde pozitif etkisi vardir.

H6: "Danışma" değişkeninin "Adalet" değiş̧keni üzerinde pozitif etkisi vardır.

H7: "Danışma" değişkeninin "Direnç" değişseni üzerinde negatif etkisi vardır. 
Çetin Gerger, G. \& F. Bakar \& A. Gerçek (2016), “Türkiye’de Mali Müşavirlerin Mükellef Haklarına

ve Gelir İdaresine Bakışını Etkileyen Faktörlerin Belirlenmesi”, Sosyoekonomi, Vol. 24(29), 45-71.

H8: “Güvenilir Muamele” değişkeninin “Güven” değişkeni üzerinde pozitif etkisi vardir.

H9: "Güvenilir Muamele" değişkeninin "Direnç" değişkeni üzerinde negatif etkisi vardır.

H10: “Adalet” değişkeninin “Güven” değişkeni üzerinde pozitif etkisi vardır.

H11: “Adalet" değişkeninin "Direnç” değişkeni üzerinde negatif etkisi vardır.

H12: "Uygun Çıktılar” değişkeninin “Güven” değişkeni üzerinde pozitif etkisi vardir.

H13: "Uygun Çıktılar” değişkeninin "Direnç” değişkeni üzerinde negatif etkisi vardir.

H14: "Teknoloji Kullanımı” değişkeninin "Güven” değişkeni üzerinde pozitif etkisi vardır.

H15: "Teknoloji Kullanımı" değişkeninin "Direnç” değişkeni üzerinde negatif etkisi vardır.

H16: “Güven” değişkeninin "Direnç” değişkeni üzerinde negatif etkisi vardır.

Araştırmada dişsal değişkenler olarak saygı, mükellef haklarına yaklaşım, danışma, güvenilir muamele, uygun çıktılar ve teknoloji kullanımı ele alınmıştır. Adalet ve tarafsızlık, güven ile direnç değişkenleri ise içsel değişkenlerdir. Bu değişkenlerden adalet ve tarafsızlık ile güven değişkenleri aynı zamanda aracı değişken özelliğine sahiptir.

\subsection{Araştırmanın Metodolojisi}

Araştırmada veri toplama aracı olarak anket yöntemi kullanılmıştır. Bu anket Murphy (2004), Hung, Chang ve Yu (2006), Schaupp, Carter ve McBride (2010) ve Çetin Gerger (2011) tarafindan daha önce uygulanmış anketlerden yararlanılarak geliştirilmiştir. Anketi oluşturan toplam 54 sorunun 46'sı mali müşavirlerin gelir idaresine güven ve direncini belirleyen faktörlerin tespitine yönelik olup, bu sorularda 5 'li Likert ölçeğinin kullanılması tercih edilmiştir. Geriye kalan 8 soru ise katılımcıların yaş, cinsiyet, medeni durum, eğitim durumu, faaliyet alanı, iş deneyimi, gelir durumu ve oturulan ili belirlemeye yöneliktir.

Araştırmanın evreni; mükelleflerin vergileme işlemlerini yürüten ve onların temsilcisi konumunda olan serbest muhasebeci mali müşavirlerden oluşmaktadır. Söz konusu TÜRMOB'a kayıtlı serbest muhasebeci mali müşavirlerin sayısı yaklaşık 91.000 kişi olduğundan, örneklem büyüklüğü \%5 hata payı ve \%99 güven aralığında 659 olarak belirlenmiştir (Bkz. TÜRMOB). Araştırmada açıklayıcı faktör analizi ve yapısal eşitlik modellemesi gibi üst düzey analizler yapılacağı için, araştırmanın amacına uygunluğu nedeniyle örneklemin belirlenmesinde "tesadüfi örnekleme" yöntemlerinden "zümrelere 
göre örnekleme" yönteminin kullanılması tercih edilmiştir. Her zümreden örnekleme girecek birimler "orantılı paylaştırma" yöntemi ile seçilmiştir. Türkiye genelini temsil etmek üzere İstatistik Bölge Birimleri Sınıflandırması Düzey-1 (NUTS-1) bölgelerindeki mükellef dağılımları esas alınarak anketler İstanbul, Balıkesir, İzmir, Bursa, Antalya, Kayseri, Samsun, Trabzon, Ankara, Erzurum, Malatya ve Gaziantep il merkezlerinde uygulanmıştır. Böylece ülkemizin tüm bölgelerinden orantılı verilerin elde edilmesi sağlanarak ana kitlenin mükellef hakları algısı ve gelir idaresine bakışı en doğru şekilde tespit edilmeye çalışılmıştır. $\mathrm{Bu}$ illerde uygulanan anketlerin dağılımı şu şekildedir:

Tablo: 2

Meslek Mensuplarına Uygulanan Anket Formlarının İllere Göre Dağılımı

\begin{tabular}{|c|c|c|c|c|c|}
\hline $\begin{array}{c}\text { Nuts 1 } \\
\text { Sira No }\end{array}$ & İl & Sayı & $\begin{array}{c}\text { Nuts 1 } \\
\text { Sira No }\end{array}$ & II & Sayı \\
\hline 1. & İstanbul & 344 & 7. & Samsun & 10 \\
\hline 2. & Balıkesir & 11 & 8. & Trabzon & 10 \\
\hline 3. & İmir & 66 & 9. & Ankara & 115 \\
\hline 4. & Bursa & 44 & 10. & Erzurum & 10 \\
\hline 5. & Antalya & 30 & 11. & Malatya & 10 \\
\hline 6. & Kayseri & 13 & 12. & Gaziantep & 17 \\
\hline
\end{tabular}

Araştırma verilerinin toplanması için geliştirilen anket, araştırma şirketi aracılığıyla Haziran - Temmuz 2013'te NUTS-1 bölgelerindeki illerde bulunan serbest muhasebeci mali müşavirlere uygulanmıştır. Yapısal eşitlik modelleme yaklaşımı açısından veri kalitesi önem arz ettiğinden, örneklem hacminin daha önce hesaplanan örneklem hacminden daha fazla olması hedeflenmiştir. Bu nedenle 680 kişiye anket uygulanmıştır. Uygulanan anketlerin bazılarında görülen veri eksiklikleri ve bilgi tutarsızlıkları nedeniyle; mali müşavirlerin cevaplandırdığı anketlerden 665 tanesi analize tabi tutulmuştur.

Ana araştırma aşamasına geçilmeden önce 60 mali müşavir üzerinde pilot araştırma yapılmış ve önerilen teorik modelin ölçeğinin güvenilirlik ve geçerliliği test edilmiştir. Yapılan güvenilirlik analizinde ölçeğin içsel tutarlılığını olumsuz etkileyen ölçek ifadelerinin tespiti yapılarak içsel tutarlılığa katkı sağlamayan veya olumsuz katkı sağlayan 6 adet soru ölçekten çıkarılmıştır. Böylece anket formunda toplam 48 soru kalmıştır. Yapılan geçerlilik analizinde teorik modelde yer alan değişkenlerin birbirleriyle ilgileşim (korelasyon) değerlerine bakılarak ayırt edici sorular olup olmadığı analiz edilmiştir. Güvenilirlik ve geçerlilik analizlerinin sonucunda yapılan açıklayıcı faktör analizi ile teorik modelde ileri sürülen faktörleri oluşturan değişkenler test edilmiştir. 


\subsection{Verilerin Analizi ve Bulgular}

\subsection{1. Örnekleme İlişkin Demografik Bilgiler}

Meslek mensuplarına uygulanan ankette; yaş, cinsiyet, medeni durum, eğitim durumu, mesleki unvan, iş deneyimi ve gelir durumuna ilişkin bilgiler toplanmıştır. Bunların betimsel istatistik sonuçları aşağıdaki gibidir:

Tablo: 3

Meslek Mensuplarına Uygulanan Ankete Ait Demografik Bilgiler

\begin{tabular}{|c|c|c|c|c|c|}
\hline & Cevaplar & Frekans & Yüzde & Geçerli \% & Kümülatif \% \\
\hline \multirow{6}{*}{$\approx$} & $18-30$ & 140 & 21,1 & 21,2 & 21,2 \\
\hline & $31-40$ & 215 & 32,3 & 32,6 & 53,9 \\
\hline & $41-50$ & 175 & 26,3 & 26,6 & 80,4 \\
\hline & $51-60$ & 74 & 11,1 & 11,2 & 91,7 \\
\hline & $61+$ & 55 & 8,3 & 8,3 & 100 \\
\hline & Kayıp veri & 6 & 0,9 & - & \\
\hline \multirow{2}{*}{ 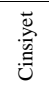 } & Kadın & 153 & 23 & 23 & 23 \\
\hline & Erkek & 512 & 77 & 77 & 100 \\
\hline \multirow{3}{*}{ 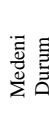 } & Evli & 483 & 72,6 & 73,2 & 73,2 \\
\hline & Bekar & 177 & 26,6 & 26,8 & 100 \\
\hline & Kayıp veri & 5 & 0,8 & - & \\
\hline \multirow{5}{*}{ 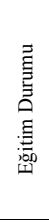 } & İlköğretim & - & - & - & - \\
\hline & Lise & 73 & 11 & 11 & 11 \\
\hline & Önlisans & 36 & 5,4 & 5,4 & 16,4 \\
\hline & Lisans & 526 & 79,1 & 79,1 & 95,5 \\
\hline & Lisansüstü & 30 & 4,5 & 4,5 & 100 \\
\hline \multirow{4}{*}{ 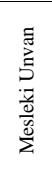 } & Serbest Muhasebeci & 150 & 22,6 & 22,7 & 22,7 \\
\hline & Serbest Muhasebeci Mali Müşavir & 487 & 73,2 & 73,7 & 96,4 \\
\hline & Yeminli Mali Müşavir & 24 & 3,6 & 3,6 & 100 \\
\hline & Kayıp veri & 4 & 0,6 & - & \\
\hline \multirow{6}{*}{ 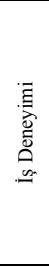 } & $0-5$ & 64 & 9,6 & 9,7 & 9,7 \\
\hline & $6-10$ & 126 & 18,9 & 19 & 28,7 \\
\hline & $11-15$ & 143 & 21,5 & 21,6 & 50,2 \\
\hline & $16-20$ & 98 & 14,7 & 14,8 & 65 \\
\hline & $21+$ & 232 & 34,9 & 35 & 100 \\
\hline & Kayıp veri & 2 & 0,3 & - & \\
\hline \multirow{2}{*}{ 妾 } & $0-10.000$ TL arası & 245 & 36,8 & 40,7 & 40,7 \\
\hline & $10.001-25.000 \mathrm{TL}$ aras1 & 147 & 22,1 & 24,4 & 65,1 \\
\hline
\end{tabular}


Çetin Gerger, G. \& F. Bakar \& A. Gerçek (2016), “Türkiye'de Mali Müşavirlerin Mükellef Haklarına ve Gelir İdaresine Bakışını Etkileyen Faktörlerin Belirlenmesi”, Sosyoekonomi, Vol. 24(29), 45-71.

\begin{tabular}{|c|c|c|c|c|c|}
\hline & Cevaplar & Frekans & Yüzde & Geçerli \% & Kümülatif \% \\
\hline \multirow{10}{*}{$\approx$} & $18-30$ & 140 & 21,1 & 21,2 & 21,2 \\
\hline & $31-40$ & 215 & 32,3 & 32,6 & 53,9 \\
\hline & $41-50$ & 175 & 26,3 & 26,6 & 80,4 \\
\hline & $51-60$ & 74 & 11,1 & 11,2 & 91,7 \\
\hline & $61+$ & 55 & 8,3 & 8,3 & 100 \\
\hline & Kayıp veri & 6 & 0,9 & - & \\
\hline & $25.001-58.000 \mathrm{TL}$ aras1 & 111 & 16,7 & 18,4 & 83,6 \\
\hline & 58.001 TL ve fazlas 1 & 99 & 14,9 & 16,4 & 100 \\
\hline & Kayıp veri & 63 & 9,5 & - & \\
\hline & Toplam & 665 & 100 & 100 & \\
\hline
\end{tabular}

Ankete katılan 665 meslek mensubuyla ilgili demografik bilgilerin yer aldığ 1 Tablo 3 incelendiğinde aşağıdaki sonuçlar görülebilir:

Ankete katılan 140 kişinin 18-30 yaş aralığında (\%21,1), 215 kişinin 31-40 yaş aralı̆̆ında (\%32,3), 175 kişinin 41-50 yaş aralığında (\%26,3), 74 kişinin 51-60 yaş aralığında $(\% 11,1)$ ve 55 kişinin 61 ve üzeri yaşlarda $(\% 8,3)$ oldukları ve ankete katılan 6 kişinin $(\% 0,9)$ bu soruya yanıt vermediği anlaşılmaktadır.

Aynı tablo incelendiğinde örneklemi oluşturan meslek mensuplarının \%77'sinin (512 kişi) erkek, \%23'ünün (153 kişi) ise kadın olduğu görülmektedir. Bu soruya yanıt vermeyen meslek mensubu bulunmamaktadır. Yine ankete katılanların \%72,6's1 (483 kişi) evli, \%26,6'sı (177 kişi) ise bekar olduğunu beyan etmiştir. Ayrıca ankete katılanların $\% 0,8$ 'i (5 kişi) bu soruya yanıt vermemiştir.

Ankete katılan meslek mensuplarından 73 kişinin (\%11) lise mezunu, 36 kişinin $(\% 5,4)$ önlisans mezunu, 526 kişinin $(79,1)$ üniversite mezunu olduğu ve 30 kişinin $(\% 4,5)$ lisansüstü eğitimini tamamladığg görülmektedir. Bu soruya yanıt vermeyen meslek mensubu bulunmamaktadır. Günümüzde meslek mensuplarının mesleğe giriş şartları da göz önüne alınınca, ankete katılanların ağırlıklı olarak yüksek eğitim görmüş olmaları doğaldır.

Tablo incelendiğinde ankete katılan meslek mensuplarının mesleki unvanları konusunda 150 kişi $(\% 22,6)$ serbest muhasebeci, 487 kişi $(\% 73,2)$ serbest muhasebeci mali müşavir ve 24 kişi $(\% 3,6)$ yeminli mali müşavir olduğunu beyan etmiştir. 4 kişi $(\% 0,6)$ ise mesleki unvanı konusunda bilgi vermemiştir.

Yine aynı tablodaki meslek mensuplarının iş deneyimi sürelerinin dağılımı incelendiğinde, $0-5$ yıl arası iş deneyimine sahip olanların sayısının 64 kişi (\%9,6), 6-10 yıl arası iş deneyimine sahip olanların 126 kişi $(\% 18,9), 11-15$ yıl arası iş deneyimine sahip olanların sayısının 143 kişi $(\% 21,5), 16-20$ yıl arası iş deneyimine sahip olanların 98 kişi $(\% 14,7)$ ve son olarak 21 yıl ve üzeri iş deneyimine sahip olanların sayısının da 232 kişi $(\% 34,9)$ olduğu anlaşılmaktadır. Ayrıca 2 kişinin ise $(\% 0,3)$ bu soruya yanıt vermediği 
görülmüştür. Bu durumda ankete katılan meslek mensuplarının çoğunluğunun uzun yıllardır faaliyetine devam ettiği anlaşılmaktadır.

Örneklemi oluşturan meslek mensuplarının gelir durumları ile ilgili, 245 kişinin $(\% 36,8)$ y1llık 10.000 TL'ye kadar gelir elde ettiği, 147 kişinin $(\% 22,1) 10.001$ - 25.000 TL arası gelir elde ettiği, 111 kişinin (\%16,7) 25.001 - 58.000 TL arası gelir elde ettiği ve 99 kişinin (\%14,9) 58.001'den fazla gelir elde ettiği görülmüştür. Ayrıca 63 meslek mensubu ise $(\% 9,5)$ gelir durumu hakkında bilgi vermemiştir.

\subsubsection{Yapısal Eşitlik Modelinin Analizi ve Bulgular}

Yapısal eşitlik modeli uygulamasında öncelikle açıklayıcı faktör analizi yapılarak, örtük değiş̧kenleri oluşturan gözlenebilir soruların ilgili faktörlerin altında toplanıp toplanmadığı ve daha sonra, uyum iyiliği istatistiklerine bakılarak oluşturulan modelin anlamlılı̆̆ı test edilmiştir. Modelde yer alan faktörler belirlenip, modelin anlamlı olduğu ortaya konulduktan sonra; yapısal eşitlik modelinde yer alan hipotezlerin yorumu ve yol analizlerinin yapılmasına geçilmiştir. Bu analizlerin yapılması için SPSS 22 ve LISREL 9.1 paket programı kullanılmıştır.

Çalışmada serbest muhasebeci mali müşavirlere uygulanan anket sorularının güvenilirliği ölçmek için en çok kullanılan güvenilirlik katsayısı olan Cronbach $\alpha$ katsayısı kullanılmıştır. Tüm soru grupları için Cronbach $\alpha$ değeri 0,831 olarak hesaplanmıştır. Bu değerin 0,80'in üzerinde olması, kullanılan ölçeğin yüksek derecede güvenilir olduğunu göstermektedir. Cronbach $\alpha$ katsayısının daha da iyileştirilmesi için "If Item Deleted" hesaplaması yapılmış ve bu aşamada V23 ve V44 numaralı sorular silinmiştir. Böylece Cronbach $\alpha$ değeri 0,851 olarak bulunmuştur.

Yapılan faktör analizinin anlamlı olması, KMO ve Bartlett testi ile elde edilen katsayıların anlamlı olmasına bağlı olduğundan, faktör analizi öncesinde bu testler uygulanmıştır. Uygulanan anketin KMO örnekleme yeterliliği ölçüsü 0.892 olarak bulunmuştur. Verilere uygulanan Bartlett'in küresellik testi anlamlı çıkmıştır $[\chi 2=$ $7180.600, \mathrm{df}=465(\mathrm{p}=0.000)]$. Bu sonuçlar, faktör analizinin uygulanabilirliğini ve değişkenler arasındaki korelasyonun varlığını göstermektedir.

Güvenilirliğin sağlanmasının ardından analize başlamadan önce, anket formunda yer alan soru gruplarının yapısal geçerliliği test edilmiştir. Bu amaçla açıklayıcı faktör analizi uygulanarak, soru gruplarının aynı kavramı ölçüp ölçmedikleri analiz edilmiştir. Faktör analizi sırasında "Anti-image" matrisinde V15 ve V22 numaralı sorularının değeri 0,50 'nin altında kaldığından analizden çıkartılmıştır. Daha sonra "Communality" değeri 0,50'nin altında kaldığından V30, V32, V37, V42, V43 ve V47 numaralı sorular da silinmiştir. V24 numaralı soru ilgili faktörü ölçen tek soru kaldığından, meslek mensupların gelir idaresine güven ve dirençlerini belirlemede "Güvenilir Muamele" faktörü modelden çıkartılmıştır. V17, V20 ve V48 numaralı soruların faktör yükleri 0,50'den düşük çıktığından, bunlar da modele dâhil edilmemiştir. Sonuç olarak geriye kalan 26 değişkenin 
toplam varyansın \%61.250'sini açıkladığı ve öz değeri 1'den büyük 8 faktör altında toplandığı görüldüğünden, bunlar yapısal eşitlik modellemesine dâhil edilmiştir.

Yapısal eşitlik modelinin tümünün anlamlılığının test edilmesi için kullanılan en temel ölçüt ki-kare $(\chi 2)$ değeridir. Ankete katılan 665 meslek mensubu için ki-kare değeri 791.19 (serbestlik derecesi 277) olarak bulunmuştur. Bulunan bu değer örneklem hacminden etkilendiğinden, bu değerin serbestlik derecesine bölünmesiyle elde edilen ve daha sağlıklı bir ölçü olan CMIN/DF değerine bakılmıştır. Bu değer 2.856 olarak bulunmuştur (791.19 / $277=2,856)$. Bu değer 2 ile 5 arasında ise modelin iyi bir model, 2 'den küçük ise modelin çok iyi bir model olduğu söylenir. Elde edilen değerin 2,856 olması, modelin iyi bir model olduğu anlamına gelmektedir.

\section{Sekil: 2}

\section{Meslek Mensupları Açısından GiDiM'in LISREL Paket Programındaki Yapısı}

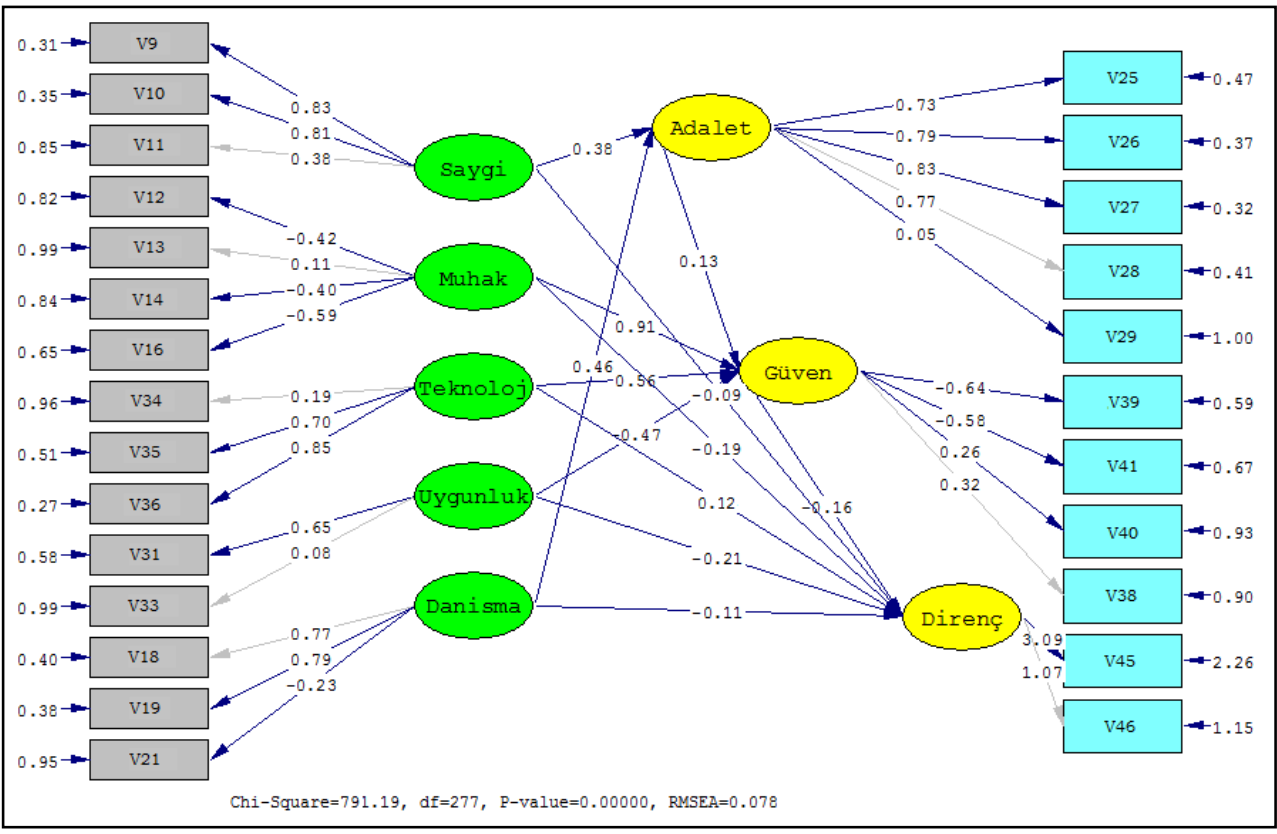

Modelin genel anlamlılığının test edilmesinde kullanılan bir diğer ölçüt olarak RMSEA (Yaklaşık Hataların Ortalama Kare Kökü) ele alınmıştır. Oluşturulan model için RMSEA değeri 0,078 olarak elde edilmiştir. Kabul edilebilir bir uyumdan söz edebilmek için bu ölçütün RMSEA $\leq 0,08$ arasında olması gerekir. Bulunan değer $(0,078)$ bu ölçüt değere uygun olduğu için, modelin genel anlamlılığının iyi olduğu anlaşılmıştır. Modelin anlamlılığını belirleyen diğer uyum iyiliği istatistikleri arasında gelen AGFI değeri 0.873, SRMR değeri 0.073 ve CFI değeri de 0.963 olarak bulunmuş olup, bu değerlerin uygun 
olduğu görülmüştür. Bu ölçütler dışında modelin anlamlılığını ölçen farklı ölçütler de bulunmaktadır. $\mathrm{Bu}$ ölçütlerden hangilerinin diğerlerinden daha sağlıklı sonuçlar verebildiğine ilişkin genel kabul görmüş bir kriter yoktur. Dolayısıyla modelin genel anlamlılığının test edilmesinde yukarıdaki ölçütlerin sağlanmasının yeterli olduğuna karar verilmiştir.

Test edilen modelin LISREL 9.1 paket programındaki görüntüsü Şekil 2'de verilmiştir. Şekil 2'de görülen modeli test etmek amacıyla beta yüklerine (path co-efficients) de bakılmıştır. Standardize edilmiş beta yüklerinin tamamının istatistiksel olarak anlamlı olduğu görülmüştür. Beta yüklerini yorumlamak için şu kriterler kullanılmıştır: standardize edilmiş beta yükü değerleri 0.10 civarında olduğunda küçük, 0.30 civarında olduğunda orta ve 0.50’nin üstünde olduğunda ise büyüktür. Bu çalışmada, standardize edilmiş beta yüklerinin 0.09 (küçük) ile 0.91 (büyük) arasında değiştiği bulunmuştur. Böylece modeldeki faktörlerin hipotez edilen ölçme modeli tarafindan anlamlı derecede açıklandığı görülmüştür.

Araştırma modelinin LISREL 9.1 paket programında analiz edilmesi sonucunda, modelde yer alan hipotezlerin yönü ve standardize çözüm değerleri Tablo 4'de gösterilmiştir.

\section{Tablo: 4}

\section{Meslek Mensupları Açısından GİDiM Hipotezlerinin Durumu}

\begin{tabular}{|l|c|c|l|}
\hline \multicolumn{1}{|c|}{ Hipotezler } & Hipotezin Yönü & Standardize Çözüm Değeri & \multicolumn{1}{c|}{ Sonuç } \\
\hline $\mathbf{H}_{\mathbf{1}}$ Sayg1 $\rightarrow$ Adalet & + & 0.38 & Desteklendi \\
\hline $\mathbf{H}_{\mathbf{2}}$ Sayg1 $\rightarrow$ Direnç & - & -0.09 & Desteklendi \\
\hline $\mathbf{H}_{\mathbf{3}}$ Teknoloji Kullanım1 $\rightarrow$ Güven & + & 0.56 & Desteklendi \\
\hline $\mathbf{H}_{\mathbf{4}}$ Teknoloji Kullanım1 $\rightarrow$ Direnç & - & 0.12 & Desteklenmedi \\
\hline $\mathbf{H}_{\mathbf{5}}$ Mükellef Hakları $\rightarrow$ Güven & + & 0.91 & Desteklendi \\
\hline $\mathbf{H}_{\mathbf{6}}$ Mükellef Hakları $\rightarrow$ Direnç & - & -0.19 & Desteklendi \\
\hline $\mathbf{H}_{\mathbf{7}}$ Uygun Çıktılar $\rightarrow$ Güven & + & -0.47 & Desteklenmedi \\
\hline $\mathbf{H}_{\mathbf{8}}$ Uygun Çıktılar $\rightarrow$ Direnç & - & -0.21 & Desteklendi \\
\hline $\mathbf{H}_{\mathbf{9}}$ Danışma $\rightarrow$ Adalet & + & 0.46 & Desteklendi \\
\hline $\mathbf{H}_{\mathbf{1 0}}$ Danışma $\rightarrow$ Direnç & - & -0.11 & Desteklendi \\
\hline $\mathbf{H}_{\mathbf{1 1}}$ Adalet $\rightarrow$ Güven & + & 0.13 & Desteklendi \\
\hline $\mathbf{H}_{\mathbf{1 2}}$ Güven $\rightarrow$ Direnç & - & -0.16 & Desteklendi \\
\hline
\end{tabular}

H1 hipotezi; saygının adalet algısı üzerinde pozitif bir etkiye sahip olduğu şeklindedir. Modelin test edilmesinde bu etkiyi gösteren standardize çözüm değerinin +0.38 olduğu görülmüştür. Bulunan standardize değerin pozitif yönde ve değerinin anlamlı olması, saygının adalet üzerinde orta etkiye sahip bir faktör olduğunu ifade etmektedir.

$\mathbf{H}_{2}$ hipotezi; saygının gelir idaresine direnç üzerinde negatif bir etkiye sahip olduğu şeklindedir. Modelin test edilmesinde bu etkiyi gösteren standardize çözüm değerinin - 0.09 olduğu görülmüştür. Bulunan standardize değerin düşük olmasına karşılık 
anlamlı ve yine de negatif yönde olması, saygının gelir idaresine direnci belirleyen küçük etkiye sahip faktörlerden biri olduğunu göstermektedir.

H3 hipotezi; teknoloji kullanımının gelir idaresine güven üzerinde pozitif bir etkiye sahip olduğu şeklindedir. Modelin test edilmesinde bu etkiyi gösteren standardize çözüm değerinin +0.56 olduğu görülmüştür. Bulunan standardize değerin pozitif yönde ve değerinin oldukça yüksek olması, teknoloji kullanımının gelir idaresine güven üzerinde büyük etkiye sahip bir faktör olduğunu göstermektedir.

$\mathbf{H}_{4}$ hipotezi; teknoloji kullanımının gelir idaresine direnç üzerinde negatif bir etkiye sahip olduğu şeklindedir. Modelin test edilmesinde bu etkiyi gösteren standardize çözüm değerinin +0.12 olduğu görülmüştür. Bulunan standardize değer pozitif yönde olduğundan, bu hipotezin desteklenmediği anlaşılmıştır.

H5 hipotezi; mükellef haklarına yaklaşımın gelir idaresine güven üzerinde pozitif bir etkiye sahip olduğu şeklindedir. Modelin test edilmesinde bu etkiyi gösteren standardize çözüm değerinin +0.91 olduğu görülmüştür. Bulunan standardize değerin pozitif yönde ve değerinin çok yüksek olması, mükellef haklarına yaklaşımın gelir idaresine güveni belirleyen ve büyük etkiye sahip olan temel faktörlerden biri olduğunu ifade etmektedir. Bu değer mükellef haklarındaki bir puanlık artışın güven üzerinde 0.91 puanlık artışa neden olacağı anlamına gelmektedir.

Ho hipotezi; mükellef haklarına yaklaşımın gelir idaresine direnç üzerinde negatif bir etkiye sahip olduğu şeklindedir. Modelin test edilmesinde bu etkiyi gösteren standardize çözüm değerinin - 0.19 olduğu görülmüştür. Bulunan standardize değerin negatif yönde ve anlamlı olması mükellef haklarına yaklaşımın gelir idaresine direnci belirleyen faktörlerden birisi olduğunu ifade etmektedir.

$\mathbf{H}_{7}$ hipotezi; uygun çıktıların gelir idaresine güven üzerinde pozitif bir etkiye sahip olduğu şeklindedir. Modelin test edilmesinde bu etkiyi gösteren standardize çözüm değerinin -0.47 olduğu görülmüştür. Bulunan standardize değer hipoteze ters bir şekilde pozitif yönde olduğundan, bu hipotezin desteklenmediği anlaşılmıştır.

Hs hipotezi; uygun çıktıların gelir idaresine direnç üzerinde negatif bir etkiye sahip olduğu şeklindedir. Modelin test edilmesinde bu etkiyi gösteren standardize çözüm değerinin - 0.21 olduğu görülmüştür. Bulunan standardize değerin negatif yönde ve anlamlı olması uygun çıktıların gelir idaresine direnç üzerinde orta etkiye sahip bir faktör olduğunu ifade etmektedir.

H9 hipotezi; danışma ve bilgi vermenin adalet algısı üzerinde pozitif bir etkiye sahip olduğu şeklindedir. Modelin test edilmesinde bu etkiyi gösteren standardize çözüm değerinin +0.46 olduğu görülmüştür. Bulunan standardize değerin pozitif yönde ve değerinin oldukça yüksek olması, adalet algısını belirleyen orta etkiye sahip faktörlerden birisinin de danışma ve bilgi verme olduğunu göstermektedir. 
H10 hipotezi; danışma ve bilgi vermenin gelir idaresine direnç üzerinde negatif bir etkiye sahip olduğu şeklindedir. Modelin test edilmesinde bu etkiyi gösteren standardize çözüm değerinin - 0.11 olduğu görülmüştür. Bulunan standardize değerin düşük olmasına karşılık yine de negatif yönde olması, danışma ve bilgi vermenin gelir idaresine direnci belirleyen faktörlerden biri olduğunu göstermektedir.

H11 hipotezi; adalet algısının gelir idaresine güven üzerinde pozitif bir etkiye sahip olduğu şeklindedir. Modelin test edilmesinde bu etkiyi gösteren standardize çözüm değerinin +0.13 olduğu görülmüştür. Bulunan standardize değerin pozitif yönde ve anlamlı olması adalet algısının gelir idaresine güveni belirleyen faktörlerden birisi olduğunu ifade etmektedir. Adalet algısı faktörünün aynı zamanda aracı değişken olması bu ilişkiyi daha da anlamlı k1lmaktadır.

$\mathbf{H}_{12}$ hipotezi; kurumsal güvenin gelir idaresine direnç üzerinde negatif bir etkiye sahip olduğu şeklindedir. Modelin test edilmesinde bu etkiyi gösteren standardize çözüm değerinin -0.16 olduğu görülmüştür. Bulunan standardize değerin negatif yönde ve anlamlı olması kurumsal güvenin gelir idaresine direnci belirleyen bir faktör olduğunu ifade etmektedir. Kurumsal güven faktörünün aynı zamanda aracı değişken olması bu ilişkiyi daha da önemli hale getirmektedir.

Araştırma modelinin karşılaştırmasını temel alan betimleyici ölçüler ve model tutarlılığını değerlendirmek için kullanılan ölçüler özet bir biçimde Tablo 5'de verilmiştir.

Tablo: 5

Meslek Mensupları Açısından GİDiM için YEM Sonuçları

\begin{tabular}{|c|c|c|}
\hline Yapısal İlişkiler & Standartlaştırılmış Yükler & $\underset{\text { değeri }}{t-}$ \\
\hline Sayg $\rightarrow$ Adalet & 0.38 & 9.92 \\
\hline Sayg1 $\rightarrow$ Direnç & -0.09 & -1.99 \\
\hline Teknoloji Kullanımı $\rightarrow$ Güven & 0.56 & 8.56 \\
\hline Teknoloji Kullanımı $\rightarrow$ Direnç & 0.12 & 6.71 \\
\hline Mükellef Hakları $\rightarrow$ Güven & 0.91 & 14.37 \\
\hline Mükellef Hakları $\rightarrow$ Direnç & -0.19 & -7.83 \\
\hline Uygun Çıktılar $\rightarrow$ Güven & -0.47 & -6.71 \\
\hline Uygun Çıktılar $\rightarrow$ Direnç & -0.21 & -10.60 \\
\hline Danışma $\rightarrow$ Adalet & 0.46 & 5.71 \\
\hline Danışma $\rightarrow$ Direnç & -0.11 & -2.12 \\
\hline Adalet $\rightarrow$ Güven & 0.13 & 3.60 \\
\hline Güven $\rightarrow$ Direnç & -0.16 & -8.58 \\
\hline \multicolumn{2}{|c|}{\begin{tabular}{|c|} 
Yapısal Eșitlikler \\
\end{tabular}} & $\mathbf{R}^{2}$ \\
\hline \multirow{3}{*}{\multicolumn{2}{|c|}{$\begin{array}{l}\text { Adalet }=0.38 \times \text { Sayg } 1+0.46 \times \text { Danışma } \\
\text { Güven }=0.56 \times \text { Teknoloji Kullanımı }+0.91 \times \text { Mükellef Hakları }+-0.47 \times \text { Uygun Çıktılar }+0.13 \times \\
\text { Adalet } \\
\text { Direnç }=-0.09 \times \text { Saygı }+0.12 \times \text { Teknoloji Kullanımı }+-0.19 \times \text { Mükellef Hakları }+-0.21 \times \text { Uygun } \\
\text { Cıktılar }+-0.11 \times \text { Danışma }+-0.21 \times \text { Güven }\end{array}$}} & 0.59 \\
\hline & & 0.81 \\
\hline & & 0.87 \\
\hline
\end{tabular}


"Adalet" bağımlı aracı değişkenini açıkladığı varsayılan "Saygı" ve "Danışma" bağımsız değişkenlerinin ilgili katsayıları kullanılarak elde edilen yapısal eşitlik sonucunda çoklu belirlilik katsayısı R2 0.59 olarak hesaplanmıştır. Böylece "Saygı" ve "Danışma" bağımsız değişkenin "Adalet” bağımlı aracı değişkeninin \%59'unu açıkladığı 0.05 anlam düzeyinde belirlenmiştir. "Güven" bağımlı aracı değişkenini açıkladığı varsayılan "Teknoloji Kullanımı", "Mükellef Hakları", "Uygun Çıktılar” ve "Adalet” değişkenlerinin doğrudan etkileri değerlendirildiğinde, bu değişkenlerin "Güven"in \%81'ini açıkladiğ görülmüştür. "Direnç” bağımlı değişkeni ile "Saygı", "Teknoloji Kullanımı”, "Mükellef Hakları", "Uygun Çıktılar", "Danışma” ve "Güven" arasında belirtilen nedensel ilişkiler sonucunda bu değişkenlerin “Direnç”in \%87'sini açıkladığı belirlenmiştir.

Şekil: 3

Meslek Mensupları Açısından GİDiM'e Ait Yol Diyagramı ve Standartlaştırılmış Yol Katsayıları

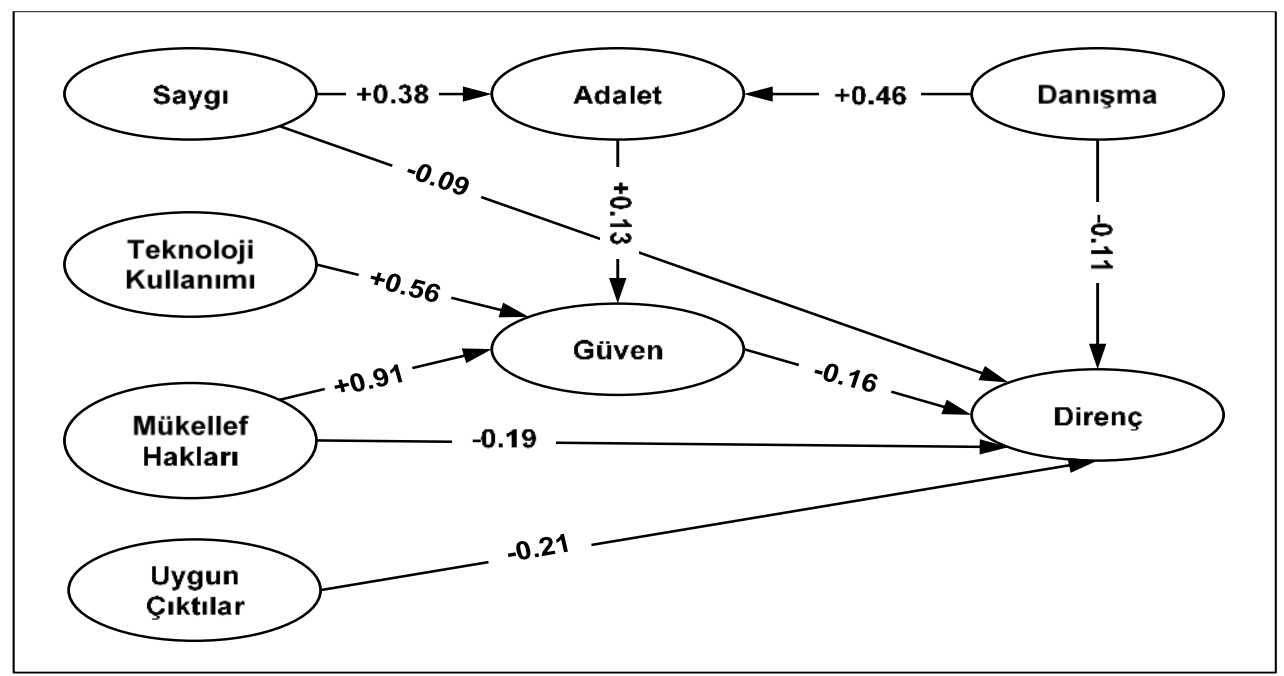

Yapısal eşitlik analizi sonucunda GIDiM üzerinde desteklenen hipotezlerin her biri için değişkenler arası ilişkilerle ait standardize çözüm değerleri Şekil 10'da gösterilmiştir. Meslek Mensupları Açısından GIDiM incelendiğinde, hipotezlerin arasındaki doğrudan etkilerin yanı sıra, aracı değişkenler üzerinde bağımsız değişkenlerin dolaylı etkileri de olduğu tespit edilmiştir. "Güven" değişkeni üzerinde; "Mükellef Hakları", “Teknoloji Kullanımı" ve "Adalet” değişkenlerinin doğrudan etkileri dışında, "Saygı" ve "Danışma" değişkenlerinin dolaylı etkisi sırasıyla 0.05 ve 0.06 olarak elde edilmiştir. Buna göre "Saygı" ve "Danışma" bağımsız değişkenlerinin "Adalet" değişkeni aracılığıyla "Güven" değişkeni üzerinde dolaylı etkisinin küçük de olsa anlamlı olduğu görülmüştür. 
Diğer taraftan "Direnç" değişkeni üzerinde "Uygun Çıktılar”, "Mükellef Hakları", "Saygı", "Danışma” ve "Güven” değişkenlerinin doğrudan etkileri sırasıyla -0.21, $-0.19,-0.09,-0.11$ ve -0.16 olarak hesaplanmış olup, bunların tamamı istatistiksel olarak anlamlı bulunmuştur. Bu değişkenler arasındaki istatistiksel olarak anlamlı bulunan ilişkiler dışında, "Direnç" bağımlı değişkeni üzerinde "Mükellef Hakları" ve "Teknoloji Kullanımı" bağımsız değişkenlerinin dolaylı etkileri de mevcuttur. "Mükellef Hakları"nın "Güven" değişkeni aracılığıyla "Direnç" üzerindeki dolaylı etkisi -0.15 olarak hesaplanmıştır. "Teknoloji Kullanımı" değişkeninin "Güven” değişkeni aracılığıyla "Direnç” üzerindeki dolaylı etkisi ise -0.09 olarak bulunmuştur. Dolayısıyla bu bağımsız değişkenlerin "Direnç" değişkeni üzerinde anlamlı dolaylı etkilerinin olduğu görülmüştür.

Diğer taraftan "Güven” aracı değişkeni ve "Direnç” bağımlı değişkeni üzerinde en etkili bağımsız değişkenin "Mükellef Hakları" olduğu görülmüştür. "Mükellef Hakları"nın doğrudan "Direnç" üzerinde orta seviyede negatif bir etkisi varken, "Güven" üzerinde çok büyük pozitif bir etkisi bulunmaktadır. Ayrıca "Mükellef Hakları"nın "Güven” değişkeni aracılığıyla "Direnç" üzerinde de anlamlı dolaylı etkisi olduğu görülmektedir. Bu nedenle "Mükellef Hakları" alanında yapılacak bir düzenleme aynı zamanda "Güven" ve "Direnç" üzerinde de etki yaratacağından, bu durum "Mükellef Hakları" alanında yapılacak çalışmaların ve izlenecek politikaların meslek mensuplarının gelir idaresine bakışını belirlemede önemli olacağını göstermektedir.

\section{Türkiye'de Mali Müşavirlerin Mükellef Haklarına ve Gelir İdaresine Bakışını Geliştirmeye Yönelik Öneriler}

Mükelleflerin muhasebe ve vergi işlemlerinde muhatap olarak kabul ettikleri meslek mensupları, idare tarafindan da mükellefin temsilcisi olarak görülmektedir. Ülkemizde vergi idaresi - mükellef ilişkilerinin kopukluğu yanında mükelleflerin idareye karşı çekingenliği ve güvensizliği sebebiyle meslek mensuplarının bunların arasındaki köprü görevleri daha önemli hale gelmektedir. Meslek mensuplarının görevleri sadece vergileme ile sınırlı olmayıp, işletme ile ilgili finansal bilgilerin tam, doğru, tarafsız, zamanlı ve kaliteli oluşturulmuş, raporlanmış ve sunulmuş olmasını da kapsamaktadır. Bu sebeple kayıt dışı ekonomi ile mücadelenin yanında vergi kayıp ve kaçaklarının önlenmesi için onların yaptıkları işlemler sistem içinde önemli bir yer bulmaktadır (Sönmez, 2014).

Verimli, adil ve kalkınmayı destekleyici olarak özetlenebilecek etkin bir vergi sistemi ve uygulamasını gerçekleştirmede, mükelleflerin vergi karşısındaki tutum ve davranışlarının bilinmesi ve değerlendirilmesi ön planda tutulmalıdır (Muter, Sakınç, Çelebi, 1993: 5). Fakat bu aktif ve pasif süje ilişkisine sadece tek taraflı bakılmaması, aynı zamanda mükelleflerin idare ile ilişkilerinde onların görüşleri üzerinde etkili olan ve "köprü" konumunda işlev gören meslek mensuplarının görüşlerinin de alınması gerekmektedir. Mali müşavirlerin de isteği bu doğrultudadır. Örneğin, mali müşavirler üzerinde yapılan bir araştırmada vergi mevzuatında yapılacak değişikliklerde meslek mensuplarının da görüşlerinin alınması gerektiği \%97,6 oranında kabul edilmiştir (Gökgöz \& Zeytin, 2012: 487). 
Meslek mensuplarının görüşlerinin alınması özellikle e-vergileme sisteminin zorunlu olarak uygulandığı Türkiye gibi ülkeler için daha önemli hale gelmektedir. Çünkü e-vergileme sistemi ilgili meslek mensubu aracılığgyla kullanılmakta, beyannameler onlar tarafindan idareye iletilmektedir. Bu sebeple serbest muhasebeci mali müşavirin mükellefidare arasındaki köprü görevi daha da önemli hale gelmektedir (Gerçek vd., 2015a: 106). Ülkemizde de vergilendirme ile ilgili ödevlerde zorunlu olarak mali müşavirlere görev düştüğü için idare tarafından onların bakış açılarını da tespit etmeye yönelik anketler yapılmalidir.

Mükelleflerin temel haklarından olan temsilci kullanma hakk1 gereği onlar, işlemlerini temsilcileri aracılığıyla gerçekleştirebilirler. Vergi mevzuatında kanuni temsilcilere ilişsin bazı hükümler yer almakla birlikte, temsil türü olarak vekalet kurumu hakkında ayrı bir düzenleme bulunmamaktadır (Gerçek vd., 2015b: 77). Bu noktada meslek mensuplarının konumları değerlendirilerek, mükellefleri temsil edebilecekleri işlemler açıkça hüküm altına alınmalıdır.

Çalışmamızdaki analiz sonuçlarına göre mali müşavirler için gelir idaresine bakışı belirleyen en önemli faktör gelir idaresine güveni pozitif etkileyen "mükellef haklarına yaklaşım" faktörüdür. Bu sebeple gelir idaresi tarafından mükellef haklarının açık bir şekilde düzenlenmesi ve bunların kanunlar tarafından korunmasının sağlanması, mükelleflerin gelir idaresine güven duyması ve dirençlerinin azalması açısından kullanışı bir araç olduğu belirlenmiştir. Diğer taraftan teknoloji kullanımının gelir idaresine güven duyulmasını belirleyen ikinci önemli faktör olduğu tespit edilmiştir. Böylece modelin revize edilmesinde mükellef haklarına yaklaşım ve teknoloji kullanımı faktörlerinin eklenmesinin önemli olduğu ortaya çıkmıştır. Danışma ve bilgi verme faktörü, meslek mensupları açısından hem adalet algısı, hem de direnci anlamlı düzeyde belirlemektedir. Dolayısıyla vergiye gönüllü uyumun artırılması açısından gelir idaresinin bir düzenleme yaparken danışma ve bilgi verme faaliyetlerinde bulunmasında yarar vardır. Modelde yer alan adalet ve güven faktörlerinin meslek mensupları açısından aracı değişken konumunda olduğu anlaşılmıştır. Gelir idaresinin mükelleflere ve meslek mensuplarına adaletli davrandıkları algısı arttıkça, gelir idaresine olan güvenin de arttığı görülmüştür. Adalet algısı ve güvenin artması ile de gelir idaresine olan direncin azaldığ 1 tespit edilmiştir. Genel olarak değerlendirilirse, gelir idaresine güven duyulması ve direncin azaltılması açısından GIDiM'de yer alan faktörlerin birbirleriyle etkileşim içinde oldukları da dikkate alınarak bunların tamamına hitap edecek düzenlemeler ve politikaların izlenmesinde yarar vardır. $\mathrm{Bu}$ faktörler açısından yapılacak her bir olumlu düzenleme mükelleflerden çok, mevzuata ve uygulamaya daha fazla hâkim olan mali müşavirlerin görüşlerini pozitif etkileyecektir.

\section{Sonuç}

Devlet ve mükellef arasındaki vergileme ilişkisinde pasif süje olan mükellefin konumu günümüzde gelir idarelerinin yeniden yapılanmasıyla ve hizmet anlayışının yenilenmesiyle birlikte değişim göstermiştir. Bu noktada devlet, sadece tek taraflı bir yaklaşımla düzenlemeler yapmamakta, aksine mükelleflerin sisteme ilişkin 
değerlendirmelerini de göz önüne almaktadır. Ayrıca pasif vergi öznesi olan mükellefin aktif vergi öznesi olan devlet karşısında sadece yükümlülüklerinin değil, haklarının düzenlenmesi gerekmektedir.

Mükellef odaklı hizmet yapısına sahip olan vergi idareleri, mükelleflerin gönüllü uyumunu artırmak için bir yandan mükellef haklarının tespiti ve açıklanmasına yönelik düzenlemeler yaparken, diğer taraftan da mükelleflerin idareye olan güveni ve / veya direncini ölçmek için alan araştırmalarına başvurmaktadır. Mükellefle idare arasındaki ilişki, mükelleflerin vergileme ile ilgili şekli ödevlerini genellikle mali temsilcileri aracılığıyla yerine getirmeleri sebebiyle dolaylı bir ilişkidir. Bu ilişkideki konumları gereği serbest muhasebeci mali müşavirler, mükelleflerin idare ve vergilendirme hakkındaki görüşleri üzerinde etkili olurlar. Özellikle e-vergilendirme sistemlerinin kullanımının zorunlu olduğu Türkiye gibi ülkelerde meslek mensuplarının "köprü" olma konumu daha da ön plandadır. $\mathrm{Bu}$ sebeple de mükellef hakları algısı ile gelir idaresine güven duyma ve/veya direnç gösterme tutumu incelenirken, mükelleflerin görüşlerinin alınması kadar meslek mensuplarınınkine de başvurulması gerekir.

Vergilendirme süreçlerinde mükelleflerden daha fazla bilgi sahibi olan ve aynı zamanda mükelleflerin yükümlülüklerini yerine getirirken onlarla birebir ilişki içinde olan mali müşavirlerin mükellef hakları algısı ve gelir idaresine bakışını belirleyen faktörlerin tespitiyle bunların yapısal eşitlik modeli yardımıyla analiz edilmesini amaçlayan bu çalışmada, Gelir İdaresine Direnç Modeli (GİDiM) geliştirilmiştir. Bu model sonucuna göre mali müşavirler için gelir idaresine bakışı belirleyen en önemli faktör gelir idaresine güveni pozitif etkileyen "mükellef haklarına yaklaşım" faktörüdür. Bu sebeple gelir idaresi tarafından mükellef haklarının açık bir şekilde düzenlenmesi ve bunların kanunlar tarafından korunmasının sağlanması, mükelleflerin gelir idaresine güven duyması ve dirençlerinin azalması açısından kullanışı bir araç olduğu belirlenmiştir. Genel olarak değerlendirildiğinde, gelir idaresine güven duyulması ve direncin azaltılması açısından GİDiM'de yer alan saygı, danışma ve bilgi verme, güvenilir muamele, adalet ve tarafsızlık, uygun çıktılar, teknoloji kullanımı, mükellef hakları faktörlerinin birbirleriyle etkileşim içinde oldukları da dikkate alınarak bunların tamamına hitap edecek düzenlemeler ve politikaların izlenmesinde yarar vardır. Bu faktörler açısından yapılacak her bir olumlu düzenleme mükelleflerden çok, mevzuata ve uygulamaya daha fazla hâkim olan mali müşavirlerin görüşlerini pozitif etkileyecektir.

\section{Kaynaklar}

Altuğ, F. \& M. Çak \& M. Şeker \& Ö. Bingöl (2010), Türkiye'de Vergi Bilinci - İstanbul Araştırması, İstanbul: İSMMMO Yayınları.

Bakar, F. (2011), “Mükellef Hakları ve Türkiye'de Mükellef Haklarının Korunmasına Yönelik Öneriler”, Uludağ Üniversitesi SBE, Yayınlanmamış Yüksek Lisans Tezi, Bursa.

Baloğlu, B. \& F. Baloğlu \& B.E. Yılmaz \& M. Şeker (2010), Sosyolojik Açıdan Türkiye'de Halkın Vergiye Bakışı, İstanbul: İstanbul Ticaret Odası Yayınları. 
Çetin Gerger, G. \& F. Bakar \& A. Gerçek (2016), “Türkiye'de Mali Müşavirlerin Mükellef Haklarına ve Gelir İdaresine Bakışını Etkileyen Faktörlerin Belirlenmesi”, Sosyoekonomi, Vol. 24(29), 45-71.

Bentley, D. (1998), “Classifying Taxpayers’ Rights”, Duncan Bentley (Ed.), Taxpayers' Rights: An International Perspective, Hyde Park Press, 16-34.

Bentley, D. (2002), "The Signifance of Declarations of Taxpayers' Rights and Global Standards for the Delivery of Tax Services by Revenue Authorities", Law Papers, Bond University, $<$ http://epublications.bond.edu.au/cgi/viewcontent.cgi?article $=1034 \&$ context=law_pubs>, 20.09.2015.

Brzezinski, B. (2009), “Taxpayer' Rights: Some Theoretical Issues”, Protection of Taxpayer's Rights European, International and Domestic Tax Law Perspective, Ed. Wlodzimiers Nykiel Malgorzata Sek, Warszawa: Wolters Kluwer Business Publications.

Çelikkaya, A. (2002), "Mükelleflerin Vergiye Gönüllü Uyumunu Etkileyen Faktörler”, e-Akademi, <http://www.e-akademi.org/makaleler/acelikkaya-1.htm>, 13.08.2015.

Çetin Gerger, G. \& A. Gerçek \& Ç. Taşkın \& F. Bakar \& S. Güzel (2013), "Determining The Factors That Affect Taxpayers' Perspective On Tax Administration: Research In Turkey", International Journal Of Economics And Finance Studies, 6(1), 18-28.

Çetin Gerger, G. \& P. Yücedoğru (2012), "Taxpayer Rights In Turkey: A Survey on Income Taxpayers in Manisa", Proceedings of the 12th European Conference on e-Government, $1,142-148$.

Çetin Gerger, G. (2011), Mükellef Hakları ve Vergiye Gönüllü Uyum, İstanbul: Legal Kitabevi.

Çiçek, H. (2006), "Psikolojik ve Sosyal Yönden Yükümlülerin Vergiye Karşı Tutum ve Tepkileri”, Istanbul SMMM Odası Dergisi, Yayın No: 65.

Demirbaş, T. \& A. Gerçek \& F. Giray \& M. Yüce \& A. Oğuzlar (2012), "Mükelleflerin e-Vergileme Sistemini Benimsemelerini Etkileyen Faktörlerin Analizi", Uludağ Üniversitesi İ̈BF Dergisi, 31(1), 59-84.

Dönmez, R. (2004), "Yükümlü Hakları: Ortaya Çıkış Nedenleri ve Bir Kavramlaştırma Denemesi”, Yaklaşım, 136, 53-58.

Erol, A. (2011), “Mükellef Hakları ve Evrensel Değerler”, Lebib Yalkın Mevzuat Dergisi, Mayıs.

Feld, L.P. \& B.S. Frey (2002), “Trust Breeds Trust: How Taxpayers are Treated”, Economics of Governance, 3, 87-99.

Gerçek, A. \& F. Giray \& T. Demirbaş \& A. Oğuzlar \& M. Yüce (2015a), “The Factors Influencing Taxpayers' Acceptance of e-Taxation System", Handbook of Research on Strategic Developments and Regulatory Practice in Global Finance, Ed. Özlem Olgu, Hasan Dinçer, Ümit Hacioğlu, USA: IGI Global, 105-121.

Gerçek, A. \& G. Çetin Gerger \& Ç. Taşkın \& F. Bakar \& S. Güzel (2015b), Mükellef Hakları: Türkiye Perspektifi ve Geliştirilmesi, Ankara: Seçkin Yayıncılık.

Gerçek, A. \& M. Yüce (1998), Mükelleflerin Vergiye Yaklaşımı Açısından Türk Vergi Sisteminin Değerlendirilmesi, Bursa: Ticaret ve Sanayi Odası Yayını.

Gerçek, A. (2006), "Vergilemede Mükellef Hakları ve Türkiye'deki Durumun Değerlendirilmesi”, Vergi Sorunları Dergisi, 209, 121-149.

GİB (2007b), Mükellef Hizmetleri Temel Teknikleri, GİB Mükellef Hizmetleri Daire Başkanlığı, Ankara, <http://www.gib.gov.tr/fileadmin/user_upload/yayinlar/mukhiz temtekkatderkit.pdf>, 05.07.2015.

Gök, K. (2007), “Vergi Direncinin Gelişimi”, Marmara Üniversitesi IIIBF Dergisi, 22(1), 143-163. 
Gökgöz, A. \& M. Zeytin (2012), "Muhasebe Meslek Mensuplarının Mesleki Faaliyetlerinde Karşılaştıkları Sorunlar ve Beklentileri: Bilecik ve Yalova İlleri Uygulaması", Süleyman Demirel Üniversitesi IIIBF Dergisi, 17(1), 477-493.

Hung, S. \& C. Chang \& T. Yu (2006), "Determinants of User Acceptance of the e-Government Services: The Case of Online Tax Filing and Payment System", Government Information Quarterly, 23(1), 97-122.

James, S. \& K. Murphy \& M. Rehinhart (2005a), "The Taxpayer's Charter: A Case Study in Tax Administration", Working Paper 62, The Australian National University.

James, S. \& K. Murphy \& M. Rehinhart (2005b), Taxpayer Beliefs and Views: Two New Surveys, <http://www98.griffith.edu.au/dspace/bitstream/handle/10072/51066/69570_1. pdf?sequence $=1>, 20.09 .2015$.

Kline, R.B. (2010), Principles and Practice of Structural Equation Modeling, New York: The Guilford Press.

Marti, L.O. \& M.S. Wanjohi \& P.O. Magutu (2010), “Taxpayers' Attitudes and Tax Compliance Behaviour in Kenya", African Journal of Business \& Management, 112-122.

Murphy, B. \& K. Murphy (2010), “The Australian Survey of Tax Scheme Investors': Survey Methodology and Preliminary Findings for the Second Stage Follow-Up Survey", Alfred Deakin Research Institute, Deakin University, Working Paper No. 4.

Murphy, K. \& K. Byng (2002), "Preliminary Findings from 'The Australian Tax System Survey of Tax Scheme Investors"”, Working Paper 40, Centre for Tax System Integrity, The Australian National University, Canberra.

Murphy, K. (2004), "The Role of Trust in Nurturing Compliance: A Study of Accused Tax Avoiders", Law and Human Behavior, 28 (2), 187-209.

Murphy, K. (2005), “Turning Resistance into Compliance: Evidence From a Longitudinal Study of Tax Scheme Investors", Working Paper 77, Centre for Tax System Integrity, The Australian National University, Canberra.

Muter, N.B. \& S. Sakınç \& A.K. Çelebi (1993), Mükelleflerin Vergi Karşısındaki Tutum ve Davranışları Araştırması, <http://kutuphane.cbu.edu.tr/db_images/site_407/file/ mukelleflerin_vergi.pdf>, 12.08.2015.

OECD (2003), “Taxpayers' Rights and Obligations”, Practice Note, <http://www.oecd.org/ dataoecd/24/52/17851176.pdf>, 18.09.2015.

OECD (2004), Compliance Risk Management: Managing and Improving Tax Compliance, <http://www.oecd.org/site/ctpfta/37212610.pdf>, 02.09.2015.

OECD (2010), “Conference on Influencing Taxpayers' Compliance Behaviour, Conference Report”, Forum on Tax Administration Information Note, CTPA, <http://www.oecd.org/tax/administration/46274793.pdf>, 25.08.2015.

OECD, (2013), Tax Administration 2013: Comparative Information on OECD and Other Advanced and Emerging Economies, OECD Publishing, <http://www.oecd-ilibrary.org/taxation/ tax-administration-2013_9789264200814-en>, 26.09.2015.

Pugesek, B.H. \& A. Tomer \& A. Von Eye (2003), Structural Equation Modeling, Cambridge University Press.

Schaupp, L.C. \& L. Carter \& M.E. Mcbride (2010), “e-File Adoption: A study of U.S. Taxpayers' Intentions", Computers in Human Behavior, 26(4), 636-644. 
Sönmez, A.H. (2014), "Vergilemede Meslek Mensuplarının Rolü, Sorunları ve Öneriler”, 1. Ulusal Mükellef Hakları Sempozyumu, 13 Aralık, Bursa.

Taşkın, Ç. \& Ö. Akat (2010), Araştırma Yöntemlerinde Yapısal Eşitlik Modelleme, Bursa: Ekin Kitabevi.

TCIT (The Chartered Institute of Taxation) (2008), A Taxpayers' Charter for the United Kingdom, <http://www.tax.org.uk/Resources/CIOT/Migrated\%20Resources/a-c/anne xe-1-thetaxpayers-charter_1.pdf>, 03.09.2015.

Tuay, E. \& İ. Güvenç (2007), Türkiye'de Mükelleflerin Vergiye Bakışı, Ankara: GİB Mükellef Hizmetleri Daire Başkanlığg1.

Tunçer, M. (2002), "Hükümet - Birey İlişkilerinin Vergi Uyumuna Etkisi ve Türkiye”, Ankara Üniversitesi SBF Dergisi, 57(3), 107-128.

Tyler, T.R. (1997), "The Psychology of Legitimacy: A Relational Perspective on Voluntary Deference to Authorities", Personality and Social Psychology Review, 1(4), 323-345.

Walsh, K. (2012), Understanding Taxpayer Behaviour - New Opportunities for Tax Administration, <http://www.esrc.ac.uk/hmrc/images/Understanding\%20Taxpayer\%20

Behaviour_tcm19-20102.pdf>, 20.09.2015.

Yaltı, B. (2006), Vergi Yükümlüsünü Hakları, İstanbul: Beta Basım Dağıtım Yayın.

Yüce, M. (1999), "Vergileme İlkeleri ve Ekonomik Konjonktür Açısından Deprem Vergilerinin Genel Bir Değerlendirilmesi”, Mevzuat Dergisi, Y.2, S.21, Eylül, <http://www.mevzuatdergisi.com/1999/09a/03.htm>, 20.09.2015. 
Çetin Gerger, G. \& F. Bakar \& A. Gerçek (2016), “Türkiye’de Mali Müşavirlerin Mükellef Haklarına ve Gelir İdaresine Bakışını Etkileyen Faktörlerin Belirlenmesi”, Sosyoekonomi, Vol. 24(29), 45-71. 